\title{
Bio-based films/nanopapers of banana tree pseudostem: From lignocellulosic wastes to added- value micro/nanomaterials
}

Barbara Maria Ribeiro Guimarães

Universidade Federal de Lavras

Mário Vanoli Scatolino ( $\square$ mario_paraiso@hotmail.com )

Federal University of Lavras

Maria Alice Martins

Embrapa Instrumentacao

Saulo Rocha Ferreira

Universidade Federal de Lavras

Lourival Marin Mendes

Universidade Federal de Lavras

José Tarcísio Lima

Universidade Federal de Lavras

Mario Guimarães Junior

Centro Federal de Educação Tecnólogica de Minas Gerais: Centro Federal de Educacao Tecnologica de Minas Gerais

Gustavo Henrique Denzin Tonoli

Universidade Federal de Lavras

\section{Research Article}

Keywords: Cellulose nanofibrils, agro-industrial wastes, bio-based material, microfibrillated cellulose (MFC), biodegradation, nanocellulose

Posted Date: May 13th, 2021

DOl: https://doi.org/10.21203/rs.3.rs-473285/v1

License: (c) (1) This work is licensed under a Creative Commons Attribution 4.0 International License.

Read Full License 
Amount of words: 12259

Bio-based films/nanopapers of banana tree pseudostem: From lignocellulosic wastes to added-value micro/nanomaterials

Barbara Maria Ribeiro Guimarães ${ }^{\mathrm{a}}$ (bmrg2115@yahoo.com.br), Mário Vanoli Scatolino ${ }^{\mathrm{a}}$ (mario_paraiso@hotmail.com), Maria Alice Martins ${ }^{\mathrm{b}}$ (maria-alice.martins@embrapa.br), Saulo Rocha Ferreirac (ferreira.sr@hotmail.com), Lourival Marin Mendesa (lourival@ufla.br), José Tarcísio Limaa (jtlima@ufla.br), Mario Guimarães Junior ${ }^{\mathrm{d}}$ (mgjunior@cefetmg.br), Gustavo Henrique Denzin Tonoli* (gustavotonoli@ufla.br)

${ }^{a}$ Department of Forest Sciences, Federal University of Lavras - UFLA, Perimetral Av., POB 3037, Lavras, MG, Brazil

${ }^{b}$ Empresa Brasileira de Pesquisa Agropecuária - EMBRAPA Instrumentação, Quinze de Novembro St., POB 741, São Carlos, SP, Brazil

${ }^{c}$ Department of Engineering, Federal University of Lavras - UFLA, Perimetral Av., ${ }^{d}$ Department of Electromechanical, Federal Center of Technological Education of Minas Gerais - CEFET, Araxá, MG, Brazil

*Corresponding author: +5535984332968

mario_paraiso@hotmail.com

Abstract: The growing demand for products with lower environmental impact and the extensive applicability of cellulose nanofibrils (CNFs) have received attention in several fields of knowledge due to their attractive properties. In this study, bio-based films/nanopapers were produced with CNFs from banana tree pseudostem (BTPT) wastes and Eucalyptus kraft cellulose (EKC) and were evaluated by their properties, such as mechanical strength, biodegradability and light transmittance. The CNFs were produced by mechanical fibrillation (after 20 and 40 passages) from suspensions of BTPT (alkaline pre-treated) and EKC. Films/nanopapers were produced by casting from both suspensions with concentrations of $2 \%$ (based in dry mass of CNF). The BTPT films/nanopapers showed greater mechanical properties, with Young's modulus and tensile strength around $2.42 \mathrm{GPa}$ and $51 \mathrm{MPa}$ (after 40 passages), respectively. On the other hand, the EKC samples showed lower disintegration in water after 24 $\mathrm{h}$ and biodegradability. The increase in the number of fibrillation cycles produced more transparent films/nanopapers and caused a significant reduction of water absorption for both raw materials. The permeability was similar for the films/nanopapers from BTPT and EKC. This study indicated that attractive mechanical properties and biodegradability could be achieved by 


\section{CNFs: Cellulose nanofibrils}

BTPT: Banana tree pseudostem

EKC: Eucalyptus kraft pulp

SEM: Scanning electron microscopy

FEG: Field emission gun

TS: $\quad$ Tensile strength

DW: Disintegration in water

WA: Water absorption

FTIR: $\quad$ Fourier transform infrared spectroscopy

WVTR: Water vapor transmission rate

Md: $\quad$ Average diameter

Sd: $\quad$ Standard deviation

T: $\quad$ Transmittance

RH: Relative humidity
51

52

53

54

1. Introduction

New research has demonstrated the potential of nanostructured films/nanopapers from lignocellulosic materials in advanced applications of great interest to society, such as: organic solar cells (Fang et al., 2014), organic sensors (Zhang et al., 2014), organic light-emitting diodes (Zhu et al., 2013), and flexible nanopaper transistors (Huang et al., 2013), among others.

The main reasons for the application of cellulose nanofibrils (CNFs) for the production of bio-based materials are their high aspect ratio, crystallinity, high capacity in forming flexible films/nanopapers, with low thermal expansion, high optical transparency, excellent mechanical properties (tensile strength and Young's modulus), emulsifying potential in suspensions, and as a barrier (to oil, oxygen and water vapor), in addition to being abundant and non-toxic. The development of new bio-based devices using nanostructures from lignocellulosic materials is a rather new but rapidly evolving research area (Siró and Plackett, 2010), as their application in 
cementitious composites (Fonseca et al., 2016), coated papers (Mirmehdi et al., 2018a; 2018b), aerogels (Zhou et al., 2016), and nanostructured films (Lopes et al., 2018), among others.

The methods commonly used for CNFs production are mechanical, chemical, physical and biological (Frone et al., 2011). Cellulose nanostructures are presented in the literature with different denominations, such as nanocrystals, nanowhiskers, nanofibrils and microfibrillated cellulose, depending on the structure of the cellulose (Nystrom et al., 2010). The CNFs show diameters varying from 10 to $100 \mathrm{~nm}$, being attained using a specialized microfibrillator (grinder) with a mechanism consisting of forcing the cellulose fibers through an opening between a rotating stone and a static one. The mechanism generates major shearing forces that break down the hydrogen bonds from the multi-layered cell walls of the fibers to individualized micro/nanofibril bundles (Siró and Plackett, 2010). In order to generate such nanostructures, the raw fibers must pass through various physical and/or chemical pretreatments. Chemical pre-treatments normally start with an alkaline treatment (Rosa et al., 2010) consisting of fiber immersion in alkali solution, usually with strong basic compounds as $\mathrm{NaOH}$, under heating and vigorous mechanical stirring. Strong alkaline compounds can penetrate the fiber structure and remove hemicelluloses and any other fiber components as the soluble extractives (Vardhini et al., 2016). Another widely used pre-treatment is the bleaching, which uses chlorinated compounds or hydrogen peroxide in intention to obtain pulp with greater whiteness. This process reduces or removes lignin from the pulp, possibly causing an increase in the cellulose content, chemical reactivity, dimensional stability, tensile properties, and roughness (Zuber et al., 2012). Due to pollutant production issues, chlorinated compounds are being avoided at this stage. The extent of these changes depends on the treatment time, temperature, alkali concentration, degree of polymerization, and source of cellulose (Samei et al., 2008).

Despite the enormous progress and great success in studies involving cellulose nanofibrils in the most diverse areas of science, there are still several challenges regarding the high costs and efficiency of the fibrillation on an industrial scale. Currently, the main source for CNFs production has been commercial kraft pulp (Tonoli et al., 2016; do Prado et al., 2018). The kraft pulp, especially from Eucalyptus, is the main product of planted forests for the purposes of cellulose production in Brazil. In the kraft pulping, wood in the form of chips is treated under pressure, in tanks called digesters, with sodium hydroxide $(\mathrm{NaOH})$ and sodium sulfide $\left(\mathrm{Na}_{2} \mathrm{~S}\right)$ in $\mathrm{pH}$ above 12 . This chemical process aims to dissolve the lignin, preserving the fiber resistance, thus obtaining a cellulosic pulp with yield between 50 - 60\% (Sixta, 2006). The uses of kraft pulp range from paper for packaging products, tissue paper for personal care (toilet paper, diaper, absorbents, paper towels and napkins) and environmental hygiene, to paper for writing and printing. The pulp from Eucalyptus are known to present short fibers, with length from 0.5 to $2.0 \mathrm{~mm}$, and generally has less strength, with high softness compared to the long 
fibers (Alves et al., 2011). The thickness of the fiber wall ranges, on average, from 2.5 to 6.0 $\mu \mathrm{m}$ (Trevisan et al., 2017). However, the use of other vegetal fibers has also been explored, such as: sawdust of Amazonian woods (Scatolino et al., 2018), banana pseudostem tree fiber (Elanthikkal et al., 2010), pineapple (Abraham et al., 2011), jute (Fonseca et al., 2019), palm tree (Okahisa et al., 2018), cotton (Chen et al., 2014), sisal (Santana et al., 2017), bamboo (Guimarães Jr. et al., 2018), oat straw (do Lago et al., 2020), cocoa shell (Souza et al., 2019), and red cedar bark (Zhang et al., 2019), among others.

Agricultural activity in Brazil generates several types of waste that could be a source of vegetal fibers, mainly at post-harvesting in large plantations. Banana cultivation represents an area of approximately 450,000 ha of the country and produces 6,750,000 t, which makes Brazil the fourth largest world producer (FAO, 2018). The banana tree wastes generated include the fruit skin, pseudostem, leaves and the banana peduncle (Souza et al., 2010). It is estimated that for each ton of industrialized banana, approximately 3 tons of pseudostem are generated (Padam et al., 2014). Mitigation measures for a sustainable banana production chain should focus on the reduction of residues and on ensuring their application in other chains and products, looking for reduction of the $\mathrm{CO}_{2}$ footprint.

Since these wastes are considered lignocellulosic materials, the production of CNFs from them aiming to develop added-value products could be a promising alternative. The novelty here is the scientific data contribution regarding the production and properties of the biodegradable films/nanopapers, mainly about their water vapor permeability, light transmittance, contact angle with water and biodegradability of the films/nanopapers produced with banana pseudosteam residues. These are important technical-scientific knowledge that are scarse and insufficient in literature for up-scaling packaging applications for example. Packaging industries are looking for those information and knowledge for advancement in the pre-screening of renewable raw materials for micro/nanofibrils production and application in substitution of petroleum-based polymers. Biodegradable and recyclable polymers with high barrier properties are very relevant for multilayers and novel applications in cardboards, card papers, and industrial sacks in the packaging field. Therefore, the aim of the study was to evaluate films/nanopapers of cellulose nanofibrils (CNFs) produced with agro-industrial banana tree pseudostem (BTPT) wastes and Eucalyptus kraft cellulose (EKC) for their water vapor permeability, biodegradability and light transmittance as well as their mechanical and physical properties.

\section{Materials and methods}

\subsection{Obtaining the raw materials}



cultures of the Federal University of Lavras, Lavras, State of Minas Gerais, Brazil (latitude $21^{\circ}$ $14^{\prime} \mathrm{S}$, longitude $45^{\circ} 00^{\prime} \mathrm{E}$ and altitude $900 \mathrm{~m}$ ). The BTPT was manually cut, then dried in environmental conditions (around $25^{\circ} \mathrm{C}$ ) to allow the evaporation of excess water. The wastes were ground in a knife mill (Marconi ${ }^{\circledR}$; SP, Brazil) to generate a sawdust, which was classified using the $40(0.420 \mathrm{~mm})$ and $60(0.250 \mathrm{~mm})$ mesh superposed sieves, where the fraction retained on the 60 mesh sieve was used for the next steps. The sawdust yield obtained was between $80-85 \%$, since 15 to $20 \%$ were lost through the grinding (generation of powder) and handling processes. A commercial bleached Eucalyptus kraft cellulose (EKC), supplied by Suzano Paper and Cellulose (Suzano, SP, Brazil), was used as a reference. The pulp was obtained from kraft chemical pulping process (yields of $50-60 \%$ ), with high brightness index of $92 \%$ ISO and viscosity $675 \mathrm{~cm}^{3} \cdot \mathrm{g}^{-1}$. The pulping and bleaching processes modify the nature of the chemical constituents of fibers, vessels and cellulosic fines. The mass loss after the commercial bleaching process is between $2.5-5.0 \%$.

\subsection{Chemical pre-treatments of the BTPT}

The alkaline pre-treatment of the BTPT sawdust was performed following the procedures described in Yue et al. (2015) and Fonseca et al. (2019), using $100 \mathrm{~mL}$ of solution $5 \%(\mathrm{w} / \mathrm{v})$ of $\mathrm{NaOH}$ in macropearls (Êxodo Científica Inc.; SP, Brazil) for each $5 \mathrm{~g}$ of dry sawdust, for $2 \mathrm{~h}$ at $80^{\circ} \mathrm{C}$ (water bath) under mechanical stirring (1,500 rpm). After the alkaline treatment, the samples were oven-dried at $50^{\circ} \mathrm{C}$ and forwarded to the bleaching step. The bleaching was performed using $100 \mathrm{~mL}$ of $\mathrm{H}_{2} \mathrm{O}_{2}$ (Êxodo Científica Inc.; SP, Brazil) in solution of $24 \%(\mathrm{v} / \mathrm{v})$ and $\mathrm{NaOH}$ in solution of $4 \%(\mathrm{w} / \mathrm{v})$ for $2 \mathrm{~h}$ at $80^{\circ} \mathrm{C}$ (water bath) and with mechanical stirring (1,500 rpm), for each $5 \mathrm{~g}$ of the previously alkaline-treated sawdust samples. After the sequence of treatments, the samples were washed to remove residual reagents and oven-dried at $50^{\circ} \mathrm{C}$ for $24 \mathrm{~h}$. The yields were $59 \%$ after alkaline treatment (from the BTPT natural sawdust to alkaline treated BTPT) and 60\% after bleaching (from the alkaline treated BTPT to the bleached BTPT), resulting in a total yield of 36\% (from the BTPT sawdust to the bleached BTPT). The main goals of the alkaline treatment and bleaching are to increase the brightness of the pulp and promote the removal of components such as lignin and its degradation products, extractives, metal ions, non-cellulosic carbohydrates and other impurities. In this sense, and in accordance with the environment, it was proposed the use of peroxides, instead of the chlorinated reagents (chlorine, hypochlorite and chlorine dioxide) widely used by many pulp and paper industries, due to their lower cost and a higher yield of the final product. In addition, the reagent concentrations used in the pre-treatments are low. 
The wastes of BTPT (natural sawdust, alkaline treated and bleached) and the commercial EKC were analyzed according to the amount of holocellulose (cellulose + hemicelluloses; according to Browning, 1963), cellulose (Kennedy et al., 1987), hemicelluloses, obtained by the difference between the values of holocellulose and cellulose, insoluble lignin according to NBR 7989 (ABNT, 2010) and ashes content, according to NBR 13999 (ABNT, 2003).

\subsection{Obtaining CNFs and the films/nanopapers}

The pre-treated sawdust of both the BTPT waste and the commercial EKC were dispersed separately in $6 \mathrm{~L}$ of water, obtaining a suspension of $2 \%$ concentration (based in dry mass of sawdust) and stirred for $10 \mathrm{~min}$ (200 rpm). It is important to point out that the EKC was not subjected to any other pre-treatment after being obtained from the industry. The CNFs was obtained from each raw material following the methods suggested by Guimarães Jr. et al. (2015a) and Bufalino et al. (2015), using a Masuko Supermasscolloider mechanical fibrillatory (grinder) at 1,600 rpm, keeping an average consumed electrical current of around $5 \mathrm{~A}$. The suspensions were fibrillated in cycles of 20 and 40 passages through the Supermasscolloider. The power consumption was $\sim 4.4 \times 10^{3} \mathrm{kWh} /$ ton after 20 cycles and $\sim 9.1 \times 10^{3} \mathrm{kWh} /$ ton after 40 cycles. CNFs aliquots of $40 \mathrm{~mL}$ of suspension with a concentration of $2 \%$ (based in dry mass of CNF) were poured on acrylic Petri dishes (15 cm diameter) for water evaporation in a conditioned room $\left(20 \pm 3^{\circ} \mathrm{C}\right.$; RH $\left.\sim 65 \%\right)$. Ten nanostructured film samples were produced from each of the raw materials (BTPT and EKC) after 20 and 40 passages, totaling 40 flexible films/nanopapers.

\subsection{Microstructure of the raw materials and CNFs}

A scanning electron microscope LEO EVO 40 XVP and typical light microscopy were used in order to observe the microstructure of the different raw materials (BTPT and EKC) and films/nanopapers. The samples were submitted to a metallization process by sputtering, depositing a gold layer on the sample surface. No tilt was applied. A carbon adhesive film was used to fix the samples on the stub. The working distance was $8.5 \mathrm{~mm}$ with application of high vacuum.

The structure of the CNFs after 20 and 40 passages was analyzed by scanning electron microscopy with a field emission gun (SEM/FEG). Aliquots of $0.1 \mathrm{~mL}$ of suspension samples were diluted in $10 \mathrm{~mL}$ of MilliQ water and dispersed with a Branson ultrasound equipment 101147-037 (1/2" tip diameter) operating at an amplitude of 50\%, for $3 \mathrm{~min}$ in an ice bath to avoid the heating of the sample. From the diluted and dispersed solution, a new dilution $(0.1 \mathrm{~mL}$ in $10.0 \mathrm{~mL}$ ) and a new dispersion were prepared under the same conditions. Subsequently, a drop of the doubly diluted sample was dripped onto a silicon plate and dried at room temperature. 
213 After this procedure, the samples were fixed to a sample holder using a conductive tape (carbon)

214 and kept for $24 \mathrm{~h}$ in a desiccator. A JEOL (JSM 6701) microscope equipped with a field 215 emission gun (FEG) was used with the following parameters: work distance $3 \mathrm{~mm}$, acceleration 216 voltage $4 \mathrm{kV}$ and current $10 \mu \mathrm{A}$ without sample coating. The software ImageJ $^{\circledR}$ was used to 217 determine the diameters of the samples and CNFs in detail. The average diameter of the CNFs 218 was determined by the average of 100 measurements proceeded in the SEM-FEG micrographs. 219 The desired dimensions are provided by the software, proportionally to the scale (known 220 distance) in the scanning electron microscope.

\subsection{Properties of the films/nanopapers}

223

\subsubsection{Mechanical properties}

Before the mechanical evaluations, the thickness of the samples was measured. The tensile test was carried out according to the ASTM D882-12 (2012) standard, using a TA TX 2i machine (Stable Micro Systems, England). The distance between the grips was $50 \mathrm{~mm}$ and the test speed was $0.8 \mathrm{~mm} / \mathrm{s}$. Five samples $(25 \times 100 \mathrm{~mm})$ were tested for each treatment. The tensile strength (TS) and Young's modulus were determined according to Eqs. (1) and (2),

where TS is the tensile strength (MPa); $\mathrm{M}$ is the maximum load applied to the sample $(\mathrm{N}) ; A_{0}$ is the initial cross-section area of the sample $\left(\mathrm{mm}^{2}\right)$.

Young's modulus $=S / e$

where $S$ is the stress value in the elastic region $(\mathrm{GPa})$; and $e$ is the specific elastic deformation $(\mathrm{mm} / \mathrm{mm})$ corresponding to the applied stress.

\subsubsection{Apparent density, grammage and thickness}

The apparent density of the samples can be reported as the relation between the film/nanopapers grammage and thickness, as mentioned in the TAPPI T220-om-01 (2004) standard. The grammage corresponds to a specific mass of area $\left(\mathrm{g} \mathrm{m}^{-2}\right)$, obtained in accordance with the TAPPI T410-om-02 (2004) standard. The thickness was directly determined by averaging six random measurements on the samples using a digital micrometer (resolution of 1 $\mu \mathrm{m})$. 


\subsubsection{Chemical and morphological properties}

The chemical groups of the BTPT and EKC films/nanopapers samples were determined by Fourier transform infrared spectroscopy, using a spectrophotometer Vertex 70 model (Bruker, Germany), operating in attenuated total reflection (ATR) mode. Spectra were recorded from 4,000 to $500 \mathrm{~cm}^{-1}$ spectral ranges, at a 32 -scan rate, and a $4 \mathrm{~cm}^{-1}$ spectral resolution. The effects of different passages (20 and 40x) on the surface and fracture of the samples and the presence of pores in the films/nanopapers structure were observed using a JEOL ${ }^{\circledR}$ JMS 6510 scanning electron microscope with a $10 \mathrm{kV}$ voltage. The films/nanopapers were positioned on aluminum stubs and covered with gold in order to obtain conductive samples.

\subsubsection{Contact angle}

The contact angle was evaluated by a Kruss Drop Shape Analyzer-DSA25 (Hamburg, Germany). A water drop was deposited over the sample surface through a syringe. The drop image was captured by a video camera and the contact angle between the water drop and the sample surface was measured. The test was performed at room temperature $\left(20^{\circ} \mathrm{C}\right)$. For each CNFs film/nanopaper, three measurements were performed after the drop stabilization ( $2 \mathrm{~s})$.

\subsubsection{Moisture and water absorption after $2 \mathrm{~h}$ of immersion}

The moisture was determined using the procedures described in the TAPPI T412-om-02 (2004) standard. Samples (diameter $30 \mathrm{~mm}$ ) were immersed in water for $2 \mathrm{~h}$ for evaluation of the water absorption (WA 2h) using Eq. (3).

$$
W A 2 h=\left(\frac{F m-I m}{I m}\right) \times 100
$$

where $I m$ is the initial mass of the acclimatized sample; $F m$ is the final mass of the sample after $2 \mathrm{~h}$ of water immersion.

\subsubsection{Disintegration in water $(D W)$}

Samples (diameter $30 \mathrm{~mm}$ ) were kept at $65 \% \mathrm{RH}$ and $20 \pm 3^{\circ} \mathrm{C}$, weighed and immersed in $100 \mathrm{~mL}$ of distilled water for $24 \mathrm{~h}$. The excess water was then removed, and the samples were dried at $65 \% \mathrm{RH}$ and $20 \pm 3^{\circ} \mathrm{C}$, as the initial condition, being weighed again. The disintegrated portion of the samples after the immersion (DW) was calculated according to Eq. (4). The final result was obtained from the average of three measurements for each film/nanopaper.

$$
D W 24 h=\left(\frac{I w-F w}{I w}\right) \times 100
$$


where $D W 24 \mathrm{~h}$ is the percentage of disintegrated material in water; $I w=$ sample initial mass; $F w$ $=$ sample final mass.

\subsubsection{Water vapor permeability}

The analysis of water vapor permeability of the films/nanopapers was carried out following the permeability cell methodology described in Guimarães Jr et al. (2015b). This method determines the amount of water vapor that passes through a known area of sample, induced by the vapor pressure difference between two specific points on the exterior and interior of the permeability cell. Samples with known thickness were sealed in a glass permeation cell containing silica gel (relative humidity 0\%; with no water vapor pressure), placed in a desiccator and kept at $25^{\circ} \mathrm{C}$ and relative humidity $100 \%$. The film/nanopaper was positioned in the cap of the glass bottle, so that it formed a membrane between the exterior and interior of the permeability cell (Figure 1).

Figure 1 - Scheme of permeability cell methodology for evaluation of the permeability of the films/nanopapers.

The mass of the permeability cell was measured daily for 10 consecutive days. Five samples per treatment were evaluated. The values of permeability were provided in the water vapor transmission rate (WVTR; g.day ${ }^{-1} \cdot \mathrm{m}^{-2}$ ), calculated by Eq. (5) according to ASTM E 96-00 (2000).

$$
W V T R=\frac{G}{d x A}
$$

where $W V T R$ is the water vapor transmission rate; $G / d$ is the angular coefficient from the graph obtained by the linear regression of the mass gain ( $\mathrm{g}$ ) versus conditioning time (days), and $A$ is the permeation area of the sample $\left(\mathrm{m}^{2}\right)$.

\subsubsection{Light transmittance of the films/nanopapers}

The light transmittance of the samples was measured in a Bel Spectro S-2000 spectrophotometer (Monza, Italy) operated at $600 \mathrm{~nm}$ to measure the percent transmittance (\%T), according to ASTM D1746-03 (ASTM, 2003). The films/nanopapers were cut into $3 \times 1$ $\mathrm{cm}$ pieces and positioned in the equipment to allow the spectrophotometer beam to pass through the sample without any obstacles. Three measurements were performed for each treatment. 


\subsubsection{Biodegradability}

The biodegradability test was performed by measuring the mass loss of the films/nanopapers when incubated in soil. It was evaluated according to the procedures described by Bardi and Rosa (2007). The samples were buried in simulated soil prepared with cattle manure $(23 \%)$, soil $(23 \%)$, sand $(23 \%)$ and water $(31 \%)(\mathrm{m} / \mathrm{m})$, which resulted in a final moisture of around $90 \%$. The test was carried out in a room with a monitored temperature (around $23^{\circ} \mathrm{C}$ ). Each sample (diameter $10 \mathrm{~cm}$ ) was buried separately in a soil container and their masses were monitored for 18 weeks. Five samples were evaluated per treatment. After this time, the samples were removed from the simulated soil and each sample was subjected to visual inspection by light microscopy. Visual parameters that could indicate possible degradation, with or without the direct action of the microorganisms, were evaluated, such as: the presence of small cracks, stains, any pore formation, fragmentation, changes in color, and the formation of biofilm on the film/nanopaper surface.

\section{Results and discussion}

\subsection{Mechanical properties of the films/nanopapers}

There was an increase in TS and Young's modulus with the increased number of passages through the grinder fibrillator, independently of the raw material used (Table 1). This was assumed to be due to the dense hydrogen-bonding network formed by the larger surface area of the CNF obtained (Spence et al., 2010) and the diameter reduction caused by the fibrillation cycles (Potulski et al., 2016). The average in diameter ranged from $20 \pm 5$ to $15 \pm 5$ $\mathrm{nm}$ for the BTPT CNF with the increase in the number of passages from 20 to 40 . Zuluaga et al. (2009) found diameters ranging between $40-60 \mathrm{~nm}$ for CNF bundles isolated from banana rachis, values superior to that found in this research. On the other hand, Velásquez-Cock et al. (2016) found values for diameter of nanocellulose from BTPT ranging between $15-20 \mathrm{~nm}$ after 30 cycles of mechanical fibrillation, which were close to that found in this research. The average diameter ranged from $31 \pm 23$ to $21 \pm 9 \mathrm{~nm}$ for $\mathrm{EKC}$, showing that the sequence composed of pre-treatments and mechanical treatment was effective for generating structures in nanoscale (Table 2). The lower diameter of the BTPT CNF is consequence of the weakness of these non-woody fibers that are easily deconstructed with the shearing forces during grinding.

Table 1 - Average values of tensile strength (TS) and Young's modulus of the nanostructured films/nanopapers.

\begin{tabular}{lccc}
\hline \multirow{2}{*}{ Fiber source } & \multirow{2}{*}{ Passages } & Tensile strength (TS) & Young's modulus \\
\cline { 3 - 4 } & & $\mathrm{MPa}$ & $\mathrm{GPa}$ \\
\hline BTPT & 20 & $46.3 \pm 0.5^{*}$ & $1.20 \pm 0.09$ \\
\hline
\end{tabular}




\begin{tabular}{llll}
\hline & 40 & $51.4 \pm 0.6$ & $2.42 \pm 0.10$ \\
\multirow{2}{*}{ EKC } & 20 & $23.7 \pm 1.0$ & $1.80 \pm 0.04$ \\
& 40 & $46.1 \pm 1.5$ & $2.49 \pm 0.09$ \\
\hline
\end{tabular}

*Standard deviation

Table 2 - Average and standard deviation of the CNF diameter and the maximum (Max) and minimum (Min) values measured for each fiber source.

\begin{tabular}{lcccc}
\hline \multirow{2}{*}{ Fiber source } & \multirow{2}{*}{ Passages } & \multicolumn{3}{c}{ Diameter $(\mathrm{nm})$} \\
\cline { 3 - 5 } & & Average & Max & Min \\
\hline \multirow{2}{*}{ BTPT } & 20 & $20 \pm 5^{*}$ & 41 & 5 \\
& 40 & $15 \pm 5$ & 24 & 3 \\
\multirow{2}{*}{ EKC } & 20 & $31 \pm 23$ & 78 & 6 \\
& 40 & $21 \pm 9$ & 36 & 7
\end{tabular}

*Standard deviation

The smaller diameters may explain the better performance of TS for the BTPT films/nanopapers. BTPT presented longer starting fibers $(\sim 3.4 \mathrm{~mm})$ (Figure 4$)$ compared to EKC pulp ( $\sim .6$ to $0.9 \mathrm{~mm}$ ) (Figure 5). According to Stelte and Sanadi (2009), fibrillation occurs more rapidly for long fiber species and may be obtained with lower energy consumption. The thickness of the cell wall can also result in easier fibrillation, the cell walls with lower thickness being more favorable to mechanical treatment. Ogunsile and Oladeji (2016) found 5 $\mu \mathrm{m}$ for the cell wall thickness of BTPT. Additionally, the lignin content of these films/nanopapers (Figure 2) did not have a negative effect on the tensile strength. TS in the present work ranged from 24 to $52 \mathrm{MPa}$, however it can reach 100 to $300 \mathrm{MPa}$ for CNFs films with content of lignin below 1\%, manufactured by methods such as dewatering (suction) or vacuum filtering, as reported in related reviews (Siró and Plackett, 2010; Nechyporchuk et al., 2016). The TS values of films produced with BTPT in the present work were higher than synthetic plastics such as linear low density polyethylene (LDPE), high density polyethylene (HDPE) and polypropylene (PP), used in most packages, with about 37; 7-16; 17 and $35 \mathrm{MPa}$, respectively (Auras et al., 2004; Avérous, 2004; Liu et al., 2012), and papers produced with bleached eucalyptus pulp nanofibers, with TS of around $35 \pm 10 \mathrm{MPa}$ (Malucelli et al., 2018). Li et al. (2019) produced papers using CNFs of pine bleached pulp, and vacuum filtering, followed by compression and vacuum drying in the process, for papers produced with partially fibrillated cellulose, they found TS of approximately $26 \mathrm{MPa}$. Both the EKC and BTPT films/nanopapers obtained the highest values of Young's modulus with 40 passages of fibrillation. 
Figure 2 - Chemical composition of the BTPT and EKC; $* \mathrm{ND}=$ not detected; $\mathrm{n}=$ natural; at = alkaline treated; $\mathrm{b}=$ bleached.

The significant reduction of film thickness that occurred with the increase of the number of passages from 20 to 40 (Table 3) may also have influenced their mechanical properties. More passages may have resulted in the increase of apparent density, having a positive impact on the mechanical properties. According to Potulski et al. (2016), the decrease of fiber dimensions after the mechanical fibrillation process allows greater bonding and rearrangements of the filaments, forming a more homogeneous and compact structure, and then reducing the thickness. The more compact structure is provided by improved CNF entanglement and greater interaction between them when they show a more fibrillated structure (Lavoine et al., 2012), as verified after 40 passages through the grinder fibrillator.

Table 3 - Average and standard deviation values of thickness, grammage and apparent density of the films/nanopapers.

\begin{tabular}{lcccc}
\hline Fiber source & Passages & Thickness $(\mu \mathrm{m})$ & Grammage $\left(\mathrm{g} . \mathrm{m}^{-2}\right)$ & Apparent density $\left(\mathrm{g} . \mathrm{cm}^{-3}\right)$ \\
\hline \multirow{2}{*}{ BTPT } & 20 & $62 \pm 4^{*}$ & $51.1 \pm 7.1$ & $0.82 \pm 0.06$ \\
& 40 & $48 \pm 12$ & $41.9 \pm 11.7$ & $0.86 \pm 0.03$ \\
EKC & 20 & $64 \pm 6$ & $38.2 \pm 9.8$ & $0.59 \pm 0.08$ \\
& 40 & $58 \pm 2$ & $47.9 \pm 1.9$ & $0.82 \pm 0.01$ \\
\hline
\end{tabular}

*Standard deviation

The presence of fibers with ineffective deconstruction by the fibrillation process favors failures and internal defects such as pores and microcracks, which act as stress concentration spots, reducing the mechanical strength of the samples. Parameters such as thickness and grammage require more detailed studies and with more replications in order to obtain a conclusion about their real trend regarding the number of fibrillation cycles. The morphological structures of the BTPT (Figure 3) showed a more cohesive film/nanopaper with few nonfibrillated fiber structures. On the other hand, the EKC films/nanopapers (Figure 4) presented a significant content of bundles of intact fibers of greater dimensions observed on the sample surface, which may have contributed to the lower TS.

Figure 3 - Typical scanning electron microscopy (SEM) images of BTPT films/nanopapers: a) and b) surface and fracture view, respectively (20 passages); c) and d) surface and fracture view, respectively (40 passages); e) and f) SEM/FEG micrographs of the CNFs suspension, respectively, after 20 and 40 passages. 
420 Figure 4 - Typical scanning electron microscopy (SEM) micrographs of EKC 421 films/nanopapers: a) and b) surface and fracture view, respectively (20 passages); c) and d) 422 surface and fracture view, respectively (40 passages); e) and f) SEM/FEG micrographs of the 423 CNFs suspension, respectively, after 20 and 40 passages.

The scanning electron microscopy (SEM) micrographs showed some fibers not fully fibrillated after 20 passages, mainly in the EKC films/nanopapers. Non-fibrillated fibers can be a source of defects in the samples due to the pores they cause in the microstructure. The CNF suspensions showed a slightly heterogeneous aspect after 20 passages, possibly containing nonfibrillated and long fiber fragments (Siró and Plackett, 2010). As the number of passages increased, there was a decrease of internal pores caused by a more compact and denser structure. This may have promoted a greater number of hydrogen bonds due to the greater specific contact area between the CNFs and a higher content of bonding clusters (Zimmermann et al., 2010). The images show greater individualization of the CNFs as the number of passages increases. Mechanical disintegration through the grinder resulted in fibrillar structures with diameters below $100 \mathrm{~nm}$.

\subsection{Physical properties of the films/nanopapers}

The contact angle obtained for the BTPT and EKC films/nanopapers confirms the surface structure aspects of the samples observed by SEM. The greatest angles were observed for the BTPT films/nanopapers after 20 and 40 passages, with average angles of $81^{\circ}$ and $99^{\circ}$ after $2 \mathrm{~s}$, respectively (Figure 5). For the EKC film/nanopaper, the greatest average angle with the surface $\left(65^{\circ}\right)$ was obtained after 40 cycles of fibrillation. Denser micro/nanostructure of the films with high number of passages led to higher contact angles with water.

Figure 5 - Average contact angle (after 2 s) of water with the BTPT and EKC films/nanopapers obtained after 20 and 40 passages through the grinder fibrillator.

Table 4 shows that more cycles of fibrillation produced less hydrophilic 452 films/nanopapers. The samples of both raw materials absorbed a smaller amount of water in $2 \mathrm{~h}$ 453 when comparing the 20 and 40 passages, with reduced absorption by $10 \%$ for BTPT and $27 \%$ 454 for EKC. This occurred due to the more compact organization, denser structure and less porous 
morphology, which impairs the penetration of water through the internal structures (Dufresne, 2012). More cycles of fibrillation can provide structures in nanoscale with the possibility of forming a more strongly connected network of nanofibrils when compared to fewer fibrillation cycles (Scatolino et al., 2017). Two additional factors that can also influence the resistance to water penetration are the porosity and roughness. The more homogeneous and smoother surface as verified through the morphological analyses of the films/nanopapers after 40 passages may be an effect of the increase in density. In addition, lower values of water absorption indicate stronger cohesion between the CNFs after 40 passages. This is of fundamental importance, since the possible applications for these materials (films for multilayer paper packaging, substrates for electronic devices, solar cells, sensors, loudspeaker membranes, displays, among others) may require reduced values of this parameter.

Table 4 - Average and standard deviation of disintegration in water after $24 \mathrm{~h}$ (DW 24h), moisture and water absorption after $2 \mathrm{~h}$ of immersion (WA $2 \mathrm{~h}$ ).

\begin{tabular}{lcccc}
\hline \multirow{2}{*}{ Fiber source } & \multirow{2}{*}{ Passages } & DW 24h & Moisture & WA 2 h \\
\hline \multirow{2}{*}{ BTPT } & 20 & $7.6 \pm 1.4^{*}$ & $9.8 \pm 1.2$ & $201 \pm 4$ \\
& 40 & $7.2 \pm 1.4$ & $8.1 \pm 0.2$ & $183 \pm 2$ \\
\hline \multirow{2}{*}{ EKC } & 20 & $2.8 \pm 0.9$ & $6.4 \pm 0.5$ & $172 \pm 14$ \\
& 40 & $2.3 \pm 1.0$ & $6.0 \pm 0.9$ & $125 \pm 6$ \\
\hline
\end{tabular}

\footnotetext{
* Standard deviation
}

The disintegration in water (DW 24h) for all the films ranged from 2.3 to $7.6 \%$ and showed the same behavior of the water absorption after $2 \mathrm{~h}$. The BTPT films/nanopapers reduced by $5 \%$ the disintegration in water after 40 passages. For EKC, the reduction was $17 \%$. Regarding the type of raw material, the lower disintegration in water found for the EKC films/nanopapers was probably because this raw material came from a commercial source, where they are generally subjected to controlled processes and treatments in the industry, such as reagents for hydrophobization, specific reagents for cellulose purification, and drying, among others. In this sense, the performance of commercial pulps can generally have some advantages when compared to those from agro-industrial wastes. Additionally, the BTPT presented higher content of non-cellulosic chemical components as lignin and hemicelluloses (see Figure 2), resulting in some difficulty of packing the micro/nanofibrils and lignin/hemicelluloses fragments.

The resistance of the films/nanopapers to disintegration in water may be an important issue since it can determine their final applications, as previously stated. Total disintegration in water can be required in some cases, such as in semi-finished products for cooking (Fakhouri et al., 2007), or for increasing the integrity and resistance of the coating (Gontard et al., 1994). 
Overall, the disintegration of the samples was low, since cellulose is insoluble in water due to the strong internal structural arrangement. Scatolino et al. (2017) found disintegration in water of $4 \%$ for films produced with CNFs of Eucalyptus grandis (lignin content below 1\%), and 6\% for films produced with Cordia goeldiana from Amazonia (lignin content of 6\%), considering 30 cycles of fibrillation. This disintegration is related to leaching out of soluble aggregates (hemicelluloses, residual extractives, soluble lignin, etc.) and debonding of the residual fibers and CNFs of the surface, instead of the solubility of CNF components.

More cycles of fibrillation resulted in lower WVTR for the films/nanopapers produced from EKC. This behavior was similar to that found for the parameters WA $2 \mathrm{~h}$, DW $24 \mathrm{~h}$ and moisture, which showed better performance after 40 passages. The films/nanopapers produced from BTPT did not show significant differences between 20 and 40 cycles of fibrillation for WVTR due to the overlapping standard deviations. Table 5 presents the WVTR found in this study and some other results found in the literature for several raw materials.

Table 5 - Average values of water vapor transmission rate (WVTR) of the films/nanopapers of this study and some values reported in the literature.

\begin{tabular}{lcc}
\hline Films from: & WVTR $\left(\mathrm{g} \cdot \mathrm{day}^{-1} \cdot \mathrm{m}^{-2}\right)$ & Reported in: \\
\hline BTPT 20 & $519 \pm 12^{*}$ & \\
BTPT 40 & $497 \pm 13$ & Present study \\
EKC 20 & $517 \pm 16$ & \\
EKC 40 & $476 \pm 15$ & \\
Bleached softwood nanocellulose & 686 & Stark (2016) \\
Bleached hardwood nanocellulose & 606 & Karki et al. (2020) \\
Potato starch & 1000 & Halász et al. (2015) \\
Poly-lactic acid (PLA) & 187 & Chen et al. (2014) \\
Poly-vinyl alcohol (PVA) & 30 &
\end{tabular}

* Standard deviation

The EKC films/nanopapers showed a reduction of about $8 \%$ in the WVTR. This was assumed to be due to the increase of individualized CNF, after 40 passages, with a consequent increase of the surface area. The compact and dense three-dimensional network formed by hydrogen bonds did not allow the transport of water vapor through the film/nanopaper, since there were no carbonyl and hydroxyl groups available to make bonds with the water molecules.

510 Therefore, the absence or low amount of empty spaces between the cellulose fibrils hinders the 511 diffusivity of water vapor. The improvement of barrier properties with the increase of the degree 512 of fibrillation is strongly associated with the decrease of the diffusion coefficient, caused by the 513 strong entanglements between the cellulose nanofibrils (Kaushik et al., 2010). Scatolino et al. 514 (2017) found lower results for the properties of permeability and water disintegration when 515 evaluating nanocellulose films produced with Amazonian wood species, after more fibrillation cycles. 
518 when compared to other nanostructured materials from vegetal sources reported in the literature, 519 in particular, almost the half of the WVTR values for films composed of potato starch. Films 520 produced with starch require improvements due to the hydrophilic structure resulting from the 521 presence of amylose and amylopectin in its composition (Romero-Bastida et al., 2015). 522 Excessively high values of WVTR can be explained by the existence of larger pores in the 523 microstructure of the films. The films/nanopapers from bleached wood as the raw material also 524 obtained higher values of WVTR compared to those produced in this study. The ideal structure 525 of CNFs networks is a compact complex form, presenting an obstacle to the water vapor 526 diffusion. These are potential results for packaging applications and advancement in the pre527 screening of renewable raw materials for substitution of petroleum-based polymers applied in 528 multilayer packaging. Biodegradable and recyclable polymers with high barrier properties are 529 very important for application as novel layers or in composite mixtures in cardboards, card 530 papers, and industrial sacks for packaging. Films produced from biopolymer poly-lactic acid 531 (PLA) and the biodegradable poly-vinyl alcohol (PVA), still had WVTRs dramatically inferior 532 to those produced in this study, and their use in the formulation of composite mixtures are very 533 potential. Biodegradable polymers such as the above mentioned have several established 534 applications, ranging from plastic bags and cups, and small household items to materials for 535 electrical insulation.

\subsection{Chemical structures of the films/nanopapers}

538 The chemical structures (functional groups) of BTPT and EKC films/nanopapers were compared by FTIR and the spectra indicated the expected similarities in chemical composition for all samples. In general, the appearance or disappearance of peaks was not observed in the spectrum analysis in the different raw materials used. An absorption band was observed at the onset spectrum (Figure 6) with a peak at $3,300 \mathrm{~cm}^{-1}$, corresponding to the free $\mathrm{OH}$ groups

543 (Silverstein and Webster, 2000) and to the intermolecular hydrogen bonds. It was also observed 544 that the increase in the fibrillation passages through the grinder led to increased intensity of this band for BTPT, especially for the films/nanopapers produced with CNFs with 40 passages, suggesting more exposed hydroxyl groups in the cellulose structure in comparison to the EKC

547 films/nanopapers after 40 passages. A greater number of $-\mathrm{OH}$ bonds indicates a greater interaction between fibers and consequently better mechanical performance for these samples, as previously observed in Table 1 . The BTPT film/nanopaper after 40 passages shows greater amounts of hydrogen bonds and, consequently, inter- and intramolecular bonds between fibers,

551 forming a kind of organized dense network. This leads to a greater amount of homogeneous

552 fibers in nanoscale for BTPT films/nanopapers. 
556 Figure 6 - Typical FTIR spectra for BTPT and EKC films/nanopapers obtained after 20 and 40

557 passages through the fibrillator.

558

559

The vibrations around $2,900 \mathrm{~cm}^{-1}$ are attributed to the absorption of $\mathrm{C}-\mathrm{H}$ symmetrical

560

561

562

563

564

565

566

567

568

569

570

571

572

573

574

575

576

577

578

579

580

581

582

583

584

585

586

587

588

589 and asymmetrical stretching originating from cellulose clustering, which is typical of organic materials (Silverstein and Webster, 2000). A minimal change in this region, with the increase of the number of passages, was observed for the different films/nanopapers obtained.

The peaks observed at 1,598 and $1,446 \mathrm{~cm}^{-1}$ are attributed to $\mathrm{C}=\mathrm{C}$ axial deformations of lignin aromatic rings (Alemdar and Sain, 2008; Thomas et al., 2015), demonstrating the presence of lignin in the BTPT films/nanopapers (see Figure 2) and lower intensity for EKC. A little content of $8 \%$ of lignin was found for the BTPT samples, while for EKC, no lignin content was detected.

The band at $1,022 \mathrm{~cm}^{-1}$ was attributed to -C-O-C- pyranose ring vibration (Elanthikkal et al., 2010). The crystalline regions existing in the CNF are directly related to the quality and/or quantity of cellulose present in their bonds, and probably the greatest intensity of this band occurred due to a greater reorganization after 40 passages, when followed by drying of the fibrils that compose the BTPT films/nanopapers, as reported in the methodology section. This may have occurred due to the characteristics reported in the previous sections related to the production process, such as greater surface area, smaller diameter, greater aspect ratio and greater homogeneity. This phenomenon was not observed for the EKC films/nanopapers, however. Instead, a reduction of the intensity of these bands was observed, supposedly due to some increase of the amorphous region with the increased fibrillation after 40 passages.

\subsection{Light transmittance of the films/nanopapers}

The fibrillation altered the average diameter of the CNFs, as well as the light transmittance of the films/nanopapers (Figures 7 and 8). The higher the number of passages and the degree of fibrillation, lower is the diameter of CNF, which varied from around $20 \pm 5$ to 15 $\pm 5 \mathrm{~nm}$ for BTPT and from $31 \pm 23$ to $21 \pm 9 \mathrm{~nm}$ for EKC, demonstrating the effectiveness of the mechanical fibrillation in the process to modify the raw materials from micro to nanoscale. Smaller diameters were observed for the BTPT CNF.

\section{\#\#\#\#\#\#igure 7\#\#\#\#}

Figure 7 - Typical images of the banana tree pseudostem (BTPT) structure and films/nanopapers: (a) SEM micrographs of the fibers, (b) SEM/FEG micrographs of the CNFs 
20x, and (c) CNFs 40x; (d) visual aspect and light transmittance (T) of the films/nanopapers; $\mathrm{Md}=$ average diameter; $\mathrm{Sd}=$ standard deviation.

The results demonstrated that the increase of fibrillation decreased the optical barrier for all the samples, allowing the passage of greater amount of light. The transmittance was increased by around 5\% for BTPT films/nanopapers (from 65 to 68\%) and $12 \%$ for EKC films/nanopapers (from 58 to $65 \%$ ) with more cycles of fibrillation. The high-density values of the BTPT films/nanopapers, as well as the lower diameter of their CNFs, are probably important factors that made them less opaque in relation to the EKC samples, although residual lignin could be detected in the bleached fibers of the BTPT. More compact films/nanopapers with thinner CNFs do not scatter light inside (Oivonen et al., 2015; Qing et al., 2015), allowing greater passage of light. In this sense, Nogi et al. (2013) reported that the dispersion of light was increased by wider CNFs or by lower density films/nanopapers. The considerable amounts of non-fibrillated fibers in the EKC films/nanopapers (see Figure 4), as well as the higher contents of hemicelluloses reported in previous section, contributed to the greater opacity. The high content of hemicelluloses in the CNF is assumed to interfere with the complete dispersion in water, providing lower light transmittance to the films/nanopapers (Nogi et al., 2009). Although the two raw materials evaluated in this study presented contents of non-cellulosic components in their structures, the structure of the films from both raw materials enabled the passage of light, besides to allow the visibility through its structure (Figures $7 \mathrm{~d}$ and $8 \mathrm{~d}$ ), especially the films/nanopapers produced with 40 passages.

\section{\#\#\#\#\#Figure 8\#\#\#\#\#}

Figure 8 - Typical images of the Eucalyptus kraft cellulose (EKC) structure and films/nanopapers: (a) light microscopy image of the fibers, (b) SEM/FEG micrographs of the CNFs 20x, and (c) CNFs 40x; (d) visual aspect and light transmittance (T) of EKC films/nanopapers; $\mathrm{Md}=$ average diameter; $\mathrm{Sd}=$ standard deviation .

Several factors, such as the fibril diameters, dispersion, hemicelluloses content, lignin content, suspension homogeneity and surface roughness, influence the light transmittance (Miri et al., 2015; Abral et al., 2020). An alternative that could improve the optical performance is the mixture of CNFs with other agents for production of blends. The insertion of polymeric additives and nanostructures in the matrix can greatly improve the optical behavior since the diameter of the nanostructures is less than the wavelength of visible light (400 to $800 \mathrm{~nm}$ ), allowing the complete passage of the light. Examples of polymers for blending include biopolymers such as PLA (poly-lactic acid) (Gazzotti et al., 2019) and biodegradable polymers such as PVA (poly-vinyl alcohol) (Silva et al., 2020) and starch (do Prado et al., 2018). Another 
potential example of treatment which could be used in intention to improve the transparency of the films is the use of specific enzymes on the raw material (Long et al., 2017), which can result in high quality of fibrillation, as well as chemical pre-treatments, besides the advantage of being environmentally friendly. However, enzymatic treatment is limited due to its sensitivity to different temperature ranges, $\mathrm{pH}$ and prolonged conditions. Additionally, parameters such as: the greater number of passes through the grinder fibrillator, processing of suspensions with lower concentration, chemical modifications with oxidative reagents with greater selectivity, high temperature pressing, drying temperature of raw materials and longer sonication time are examples of techniques used to obtain final products with higher transparency (Nogi et al., 2005; Nogi et al., 2009). Processes as vacuum filtration, followed by compression and vacuum drying could also be an interesting option for production of the films/nanopapers, however it could make the process more expensive and request greater energy consumption. It is important to highlight that depending on the application, transparent films are not required, since there are several possibilities for using the product where there is no requirement for total transparency. Transparency and diameter can be used to indirectly assess the degree of fibrillation of the CNFs. The diameter measurements performed on the CNFs after 20 and 40 passages indicate the efficiency of the fibrillation process, that is, their values were $20 \pm 5$ and $15 \pm 5 \mathrm{~nm}$, for BTPT and $31 \pm 23$ and $21 \pm 9 \mathrm{~nm}$ for the EKC samples, respectively. In addition to the properties abovementioned, there was an improvement in the mechanical properties of tensile strength, density, water absorption, contact angle, water vapor transmission rate; as well as the large amount of hydroxyl groups on the CNFs surface (seen in the FTIR) and film compaction (seen with SEM-FEG). All these factors enable to infer that there was an increase in the degree of fibrillation of CNFs with more passages through the grinder.

The carboxyl content may have increased after alkaline treatment and after the passages through the mechanical fibrillator. These initial processes have promoted an increase in the amount of hydroxyl groups on the surface of the CNFs due to oxidation and the increase of the surface area of the fibrillated material (deconstruction of the cell wall). Probably, the degree of polymerization may have reduced after these steps, increasing the cationic demand of the suspension. The literature shows a certain linear relation between the increase in the tensile strength and rupture stress with the number of carboxylic groups on the fiber surface (Serra et al., 2017), that is, the increase in the number of hydroxyls and carboxylate groups provides the improvement in the tensile properties of CNFs films. In addition, the strength of plain paper depends, among others, on the number of hydrogen bonds that form between cellulose fibers when water is removed from the fibrous suspension. It is then expected that CNFs, with a larger surface area and a greater number of carboxyl and hydroxyl groups (negative charges) on their 


\subsection{Biodegradability of the films/nanopapers}

The mass loss after soil incubation is a commonly used parameter for measuring changes caused by the microbial attack on polymers (Flemming et al., 1998). The mass loss increased with the increase of incubation time, independent of the raw material (Figure 9A). The total mass losses after 18 weeks (126 days) for 20 and 40 passages were $40 \%$ and $46 \%$ for the BTPT films/nanopapers and $\sim 26 \%$ and $\sim 24 \%$ for the EKC samples, respectively. Signs of degradation such as cracks, color change, roughness, and the presence of stains on the surface of the samples were observed (Figure 9B). Other factors such as the type of microorganisms and the $\mathrm{pH}$ of the soil also interfere in the biodegradability process (Doi et al., 1992; Flemming et al., 1998). A great decrease of mass was observed until the first 4 weeks (28 days) of evaluation.

\section{\#\#\#\#\#\#\#Figure 9\#\#\#\#\#\#\#\#\#}

Figure 9 - A) Mass loss of the films/nanopapers along the biodegradation and visual aspect of the samples before and after 18 weeks in simulated soil: from (a) to (d) BTPT films/nanopapers (20 and 40 passages) before and after biodegradation; from (e) to (h) EKC films/nanopapers (20 and 40 passages) before and after biodegradation; B) Typical optical microscopy images of the samples after 18 weeks after soil incubation. Red arrows show pores and stains. From (a) to (d) BTPT nanostructured films/nanopapers (20 and 40 passages) before and after biodegradation; from (e) to (h) EKC nanostructured films/nanopapers (20 and 40 passages) before and after biodegradation.

The first days of incubation correspond to the abiotic phase of biodegradation, in which the macromolecules suffer hydrolysis. The mass reduction remained stable between the $5^{\text {th }}$ week (35 days) and $10^{\text {th }}$ week (70 days), strongly decreasing again between the $11^{\text {th }}$ (77 days) and $16^{\text {th }}$ (112 days) weeks. The decomposition was observed especially for BTPT films/nanopapers. In part, this could be due to the pores observed in their cross-section (see Figure 3), which facilitated the dispersion of degrading enzymes after the microorganism's attack. A consortium of various aerobic bacteria and fungi working cooperatively degrades the cellulose to glucose and cellodextrins (Chandra and Renu, 1998).

Biomasses are known to show recalcitrance characteristics to enzymatic deconstruction, which even includes hampering on the development of biomass-based fuels and chemicals (Weiss et al., 2017; Dias et al., 2019), and refers to compositional and structural features that provide more resistance against microbial decomposition (Sollins et al., 1996). This recalcitrance is due to a number of both chemical and structural factors and is the result of millions of years of parallel evolution of plants and plant degraders (Himmel et al., 2007; Durães et al., 2020). The samples show remarkably different recalcitrance depending on the characteristics of the raw material, including biomass porosity, cellulose accessibility, degree of 
cellulose polymerization, lignin/hemicelluloses contents and microstructural aspects (Meng et al., 2017; Lu et al., 2019).

Lignin is considered to provide a physical barrier that protects the cellulose and hemicelluloses against decay enzymes (Higuchi, 1990). Despite the mechanical barrier provided by lignin, the fibrillation may result in the depolymerization (Widsten et al., 2004), softening and redistribution of fragments of this structure (Hietala et al., 2011), allowing the higher biodegradation of BTPT films/nanopapers even with a higher content of lignin.

For some authors, the removal of hemicelluloses is considered the factor with the most impact on the accessibility of cellulose in relation to delignification (Haverty et al., 2012; Pei et al., 2012). Hemicelluloses can act as a physical barrier that hinders enzymatic hydrolysis because they are between and surrounding the cellulose microfibrils in the secondary cell walls (Zhu et al., 2011). The presented biodegradation test provides an excellent basis for further and more detailed analyses of the effect of the soil on the biodegradation process of CNFs films/nanopapers produced with lignocellulosic biomasses. The incubation process in the simulated soil creates a humid and dark environment, which favors the reduction of the recalcitrance characteristics of the lignocellulosic biomass components. It can be said that BTPT films/nanopapers presented higher biodegradation in comparison to EKC films/nanopapers, which could in part be due to the reduced recalcitrance of the BTPT.

The results obtained in this research provide insights about the management of the lignocellulosic wastes obtained mainly from the processing of the banana cultivation. Thus, further insights are required for improving the efficiency of the banana production chain, reducing residual biomass wastes and $\mathrm{CO}_{2}$ footprint with their possible application in other chains and products. This research indicated the possibility of producing nanostructured materials with high mechanical qualities using residual biomass, similar to films/nanopapers produced with commercial wood pulps. Additionally, based on the attractive properties of strength and biodegradability, it is suggested that the potential of cellulose nanofibrils combined with polymers should be evaluated for purposes such as emulsifier agents, coating layers on commercial papers and cardboards, or the production of functionalized CNFs with chelating agents for the treatment of wastewater and absorption of heavy metals. The applications of these biomass wastes for the production of biodegradable films and products contribute to reduce $\mathrm{CO}_{2}$ footprint of banana production chain, reducing environmental problems and generating economic benefits for agro-industry.

\section{Conclusions and future prospects}

The study demonstrated the potential of BTPT wastes for the production of nanostructured films/nanopapers through the evaluation of their biodegradability, physical (relations with water), barrier and mechanical properties. The increase in the number of 
passages through the grinder fibrillator reduced the CNFs diameter. The higher individualization of the raw material structures led to a greater specific area and greater bonding between the CNFs after drying. Also, predominance of smaller empty spaces led to a greater apparent density and greater film/nanopaper transparency. In general, the physical and mechanical properties were improved with the increase of cycles of fibrillation due to the formation of more compact and denser structures. The BTPT films/nanopapers showed also the greatest mechanical properties after 40 passages, with a Young's modulus and tensile strength of around $2.4 \mathrm{GPa}$ and $51 \mathrm{MPa}$, respectively. Films/nanopapers produced after 40 fibrillation cycles tended to show lower WVTR, especially those from the EKC. The total mass loss after 18 weeks of soil incubation for 20 and 40 passages were $40 \%$ and $46 \%$ for the BTPT films/nanopapers, showing higher biodegradation in comparison to EKC. Further research is required to look for alternative and eco-friendly pre-treatments or fibrillation methods that are cost-effective for upscaling their application and efficient for complete fibrillation of the fiber cell wall in nanoscale. Combined with other biodegradable polymers and chelating agents, the CNFs could be used for promising purposes, such as coating layers on sack papers, cardboards, card papers, and multilayered papers for packaging, as emulsifier agents, and the production of special membranes for the absorption of heavy metals. Therefore, the production and application of BTPT nanofibrils in other chains and products may reduce $\mathrm{CO}_{2}$ footprint in the banana production chain and may support environmentally conscious decision-making by

\section{Declarations}

Ethics approval and consent to participate Not applicable.

Consent for publication Not applicable.

Availability of data and materials

The datasets supporting the conclusions of this article are included in the article. Besides, the datasets used and/or analyzed during the current study are available from the corresponding author on reasonable request.

\section{Competing interests}

The authors declare that they have no conflict of interest.

\section{Funding}

Fundação de Amparo à Pesquisa do Estado de Minas Gerais - FAPEMIG, Coordenação de Aperfeiçoamento de Pessoa de Nível Superior - CAPES (finance code 001), and Conselho Nacional de Desenvolvimento Científico e Tecnológico - CNPq (151379/19).

\section{Authors' contributions}

BMRG contributed with the writing of the initial version, review, data collection, and data analysis. MVS and MAM were major contributors in writing the manuscript, specifically writing the initial version, review, and editing of the manuscript. SRF and LMM contributed to 
the search for new raw materials resources and review. JTL, MGJ, and GHDT contributed with supervision, conceptualization, funding acquisition, and project administration. All authors read and approved the final manuscript.

Acknowledgments

The authors thank the Coordenacão de Aperfeiçoamento de Pessoa de Nível Superior (CAPES, Brazil), Conselho Nacional de Desenvolvimento Científico e Tecnológico (CNPq, Brazil), Fundação de Amparo à Pesquisa do Estado de Minas Gerais (FAPEMIG, Brazil) for their financial support. Thanks are due also to Embrapa Instrumentação (São Carlos/SP, Brazil), to the Brazilian Lignocellulosic Composites and Nanocomposites Network (RELIGAR), and to the Biomaterials Engineering Graduation Program (PPGBIOMAT-UFLA, Brazil). Finally, thanks go to the Laboratory of Electron Microscopy and Analysis of the Ultrastructural Federal University of Lavras, (http://www.prp.ufla.br/labs/microscopiaeletronica/) for the technical support for experiments involving electron microscopy.

\section{References}

ABNT - Brazilian Association of Technical Standards NBR 13999 (2003) Paper, board, pulps and wood-determination of residue (ash) on ignition at $525^{\circ} \mathrm{C}$.

ABNT - Brazilian Association of Technical Standards NBR 7989 (2010) Pulp and wooddetermination of acid-insoluble lignin. Brazilian Association of Technical Standards.

Abraham E, Deepa B, Pothan LA, Jacob M, Thomas S, Cvelbar U, Anandjiwala R (2011) Extraction of nanocellulose fibrils from lignocellulosic fibres: A novel approach. Carbohyd Polym 86:1468-1475. https://doi.org/10.1016/j.carbpol.2011.06.034

Abral H, Ariksa J, Mahardika M, Handayani D, Aminah I, Sandrawati N, Sugiarti E, Muslimin AN, Rosanti SD (2020) Effect of heat treatment on thermal resistance, transparency and antimicrobial activity of sonicated ginger cellulose film. Carbohyd Polym 240:116287. https://doi.org/10.1016/j.carbpol.2020.116287

Alemdar A, Sain M (2008) Isolation and characterization of nanofibrils from agricultural residues - Wheat straw and soy hulls. Bioresour Technol 99:1664-167. 10.1016/j.biortech.2007.04.029

Alves ICN, Gomide JL, Colodette JL, Silva HD (2011) Technological characterization of Eucalyptus benthamii wood for kraft pulp production. Ciência Florestal 21:167-174. https://doi.org/10.5902/198050982759

ASTM - American Society for Testing and Materials D1746-03 (2003) Standard test method for transparency of plastic sheeting.

ASTM - American Society for Testing and Materials D882-12 (2012) Standard test method for tensile properties of thin plastic sheeting. 
ASTM - American Society for Testing and Materials E96-00 (2000) Standard test methods for

Auras R, Harte B, Selke S (2004) An overview of polylactides as packaging materials. Macromol Biosci 4:835-864. https://doi.org/10.1002/mabi.200400043.

Avérous L (2004) Biodegradable multiphase systems based on plasticized starch: a review. J Macromol Sci - Polym Rev 44:231-274. https://doi.org/10.1081/MC- 200029326

Bardi MAG, Rosa DS (2007) Evaluation of biodegradation in simulated soil of poli ( $\varepsilon$ caprolactone), cellulose acetate and its blends. Rev Bras Aplic Vácuo 26:43-47.

Browning BL (1963) The chemistry of wood. Interscience, New York.

Bufalino L, de Sena Neto AR, Tonoli GHD, de Souza Fonseca A, Costa TG, Marconcini JM, Colodette JL, Labory CRG, Mendes LM (2015) How the chemical nature of Brazilian hardwoods affects nanofibrillation of cellulose fibers and film optical quality. Cellulose 22:3657-3672. https://doi.org/10.1007/s10570-015-0771-3

Chandra E, Renu R (1998) Biodegradable polymers. Progr Polym Sci 23:1273-1335.

Chen Mo, Wang Y, Wang L, Yin S (2014) Effects of temperature and humidity on the barrier properties of biaxially-oriented polypropylene and polyvinyl alcohol films. J Appl Pack Research. DOI: 10.14448/japr.01.0004

Chen W, Abe K, Uetani K, Yu H, Liu Y, Yano H (2014) Individual cotton cellulose nanofibrils: Pretreatment and fibrillation technique. Cellulose 21:1517-1528.

https://doi.org/10.1007/s10570-014-0172-z

Dias MC, Mendonça MC, Damásio RAP, Zidanes UL, Mori FA, Ferreira SR, Tonoli GHD (2019) Influence of hemicellulose content of Eucalyptus and Pinus fibers on the grinding process for obtaining cellulose micro/nanofibrils. Holzforsch 73:1035-1046. https://doi.org/10.1515/hf-2018-0230

do Lago RC, de Oliveira ALM, Dias MC, de Carvalho EEN, Tonoli GHD, Vilas Boas EVB, (2020) Obtaining cellulosic nanofibrils from oat straw for biocomposite reinforcement: Mechanical and barrier properties. Ind Crop Prod 148:112264.

https://doi.org/10.1016/j.indcrop.2020.112264

do Prado NRT, Raabe J, Mirmehdi S, Hugen LN, Lima LC, Ramos ALS, Guimarães Jr M, Tonoli GHD (2018) Strength improvement of hydroxypropyl methylcellulose/starch films using cellulose nanocrystals. Cerne 23:423-434. https://doi.org/10.1590/01047760201723042303

Doi Y, Kanesawa Y, Tanahashi N, Kumagai Y (1992) Biodegradation of microbial polyesters in the marine environment. Polym Degrad Stab 36:173-177.

https://doi.org/10.1016/0141-3910(92)90154-W

Dufresne, A., 2012. Nanocellulose: from nature to high performance tailored materials. Berlin: Walter De Gruyter Incorporated. 460p.

Durães AFS, Moulin JC, Dias MC, Mendonça MC, Damásio RAP, Thygesen LG, Tonoli GHD, (2020) Influence of chemical pretreatments on plant fiber cell wall and their implications on the appearance of fiber dislocations. Holzforsch. https://doi.org/10.1515/hf-2019-0237 (online) 
Elanthikkal S, Gopalakrishnapanicker U, Varghese S, Guthrie JT (2010) Cellulose microfibres produced from banana plant wastes: Isolation and characterization. Carbohyd Polym 80:852859. https://doi.org/10.1016/j.carbpol.2009.12.043

Fakhouri FM, Fontes LCB, Gonçalves PVM, Milanez CR, Steel CJ, Collares-Queiroz FP (2007) Films and edible coatings based on native starches and gelatin in the conservation and sensory acceptance of Crimson grapes. Ciênc Tecnol Alim 27:369-375.

https://doi.org/10.1590/S0101-20612007000200027

Fang Z, Zhu H, Yuan Y, Ha D, Zhu S, Preston C, Chen Q, Li Y, Han X, Lee S et al. (2014) Novel nanostructured paper with ultrahigh transparency and ultrahigh haze for solar cells. Nano Lett 14:765-773. https://doi.org/10.1021/nl404101p

FAO: Food and Agriculture Organization of the United Nations (2018) http://faostat3.fao.org/browse/Q/QC/E . Access in 02/20/2020

Flemming HC (1998) Relevance of biofilms for the biodeterioration of surfaces of polymeric materials. Polym Degrad Stab 59:309-315. https://doi.org/10.1016/S0141-3910(97)00189-4

Fonseca CS, da Silva TF, Silva MF, Oliveira IRC, Mendes RF, Hein PRG, Mendes LM, Tonoli, GHD (2016) Eucalyptus cellulose micro/nanofibrils in extruded fibercement composites. Cerne. 22:59-68. https://doi.org/10.1590/01047760201622012084

Fonseca CS, Silva MF, Mendes RF, Hein PRG, Zangiacomo AL, Savastano Jr H, Tonoli GHD, (2019) Jute fibers and micro/nanofibrils as reinforcement in extruded fiber-cement composites. Constr Build Mat 211:517-527. https://doi.org/10.1016/j.conbuildmat.2019.03.236

Frone AN, Panaitescu D, M, Donescu D (2011) Some aspects concerning the isolation of cellulose micro- and nano- fibers. UPB Sci Bullet 73:133- 152

Gazzotti S, Rampazzo R, Hakkarainen M, Bussini D, Ortenzi MA, Farina H, Lesma G, Silvani A (2019) Cellulose nanofibrils as reinforcing agents for PLA-based nanocomposites: An in situ approach. Comp Sci Technol 171:94-102. https://doi.org/10.1016/j.compscitech.2018.12.015

Gontard N, Duchez C, Cuq J-L, Guilbert S (1994) Edible composite films of wheat gluten and lipids: Water vapor permeability and other physical properties. Int J Food Sci Technol 29:3950. https://doi.org/10.1111/j.1365-2621.1994.tb02045.x

Guimarães Jr M, Botaro VR, Novack KM, Flauzino Neto WP, Mendes LM, Tonoli GHD, $\left(2015^{\text {a }}\right)$ Preparation of cellulose nanofibrils from bamboo pulp by mechanical defibrillation for their applications in biodegradable composites. J Nanosci Nanotechnol 15:6751-6768. 10.1166/jnn.2015.10854

Guimarães Jr M, Botaro VR, Novack KM, Teixeira FG, Tonoli GHD (2015b) Starch/PVAbased nanocomposites reinforced with bamboo nanofibrils. Ind Crop Prod 70:72-83. https://doi.org/10.1016/j.indcrop.2015.03.014

Guimarães Jr M, Teixeira FG, Tonoli GHD (2018) Effect of the nano-fibrillation of bamboo pulp on the thermal, structural, mechanical and physical properties of nanocomposites based on starch/poly (vinyl alcohol) blend. Cellulose. 25:1-27. https://doi.org/10.1007/s10570-018-16919 

Film and bottle through layer-by-layer deposition of green-processed cellulose nanocrystals and chitosan. Int J Polym Sci. 2015, 6p. http://dx.doi.org/10.1155/2015/954290

Haverty D, Dussan K, Piterina AV, Leahy JJ, Hayes MHB (2012) Autothermal, single-stage, performic acid pretreatment of Miscanthus $\times$ giganteus for the rapid fractionation of its biomass components into a lignin/hemicellulose-rich liquor and a cellulase-digestible pulp. Bioresour Technol 109:173-177. https://doi.org/10.1016/j.biortech.2012.01.007

Hietala M, Samuelsson E, Niinimaki J, Oksman K (2011) The effect of pre-softened wood chips on wood fibre aspect ratio and mechanical properties of wood-polymer composites. Compos A Appl Sci Manuf 42:2110-2116. https://doi.org/10.1016/j.compositesa.2011.09.021

Higuchi T (1990) Lignin biochemistry: Biosynthesis and biodegradation. Wood Sci Technol 24:23-63.

Himmel ME, Ding S-Y, Johnson DK, Adney WS, Nimlos MR, Brady JW, Foust TD (2007) Biomass recalcitrance: engineering plants and enzymes for biofuels production. Science 315:804-807. doi:10.1126/science.1137016

Huang J, Zhu H, Chen Y, Preston C, Rohrbach K, Cumings J, Hu L (2013) Highly transparent and flexible nanopaper transistors. ACS Nano 7:2106-2113. https://doi.org/10.1021/nn304407r

Karki DB, Yadav KC, Khanal H, Bhattarai P, Koirala B, Khatri SB (2020) Analysis of biodegradable films of starch from potato waste. Asian Food Sci J 14:28-40. DOI: 10.9734/AFSJ/2020/v14i330132

Kaushik A, Singh M, Verma G (2010) Green nanocomposites based on thermoplastic starch and steam exploded cellulose nanofibrils from wheat straw. Carbohyd Polym 82:337-345.

https://doi.org/10.1016/j.carbpol.2010.04.063

Kennedy F, Phillips GO, Willians PA (1987) Wood and cellulosics, industrial utilization, biotechnology, structure and properties. Ellis Horwood, Chichester.

Lavoine N, Desloges I, Dufresne A, Bras J (2012) Microfibrillated cellulose - Its barrier properties and applications in cellulosic materials: A review. Carbohyd Polym 90:735 - 764. https://doi.org/10.1016/j.carbpol.2012.05.026

Li Y, Fu Q, Rojas R, Yan M, Lawoko M, Berglund L (2017) Lignin-retaining transparent wood. Chem Sus Chem 10:3445-3451. https://doi.org/10.1002/cssc.201701089.

Li Z, Liu W, Guan F, Li G, Song Z, Yu D, Wang H, Liu H (2019) Using Cellulose fibers to fabricate transparente paper by microfibrilation. Carbohyd Polym 214:26-33. https://doi.org/10.1016/j.carbpol.2019.03.019

Liu D, Yuan X, Bhattacharyya D (2012) The effects of cellulose nanowhiskers on electrospun poly (lactic acid) nanofibres. J Mater Sci 47:3159-3165. https://doi. org/10.1007/s10853-011-6150-z

Long L, Tian D, Hu J, Wang F, Saddler J (2017) A xylanase-aided enzymatic pretreatment facilitates cellulose nanofibrillation. Bioresour Technol 243:898 904. doi:10.1016/j.biortech.2017.07.037 
Lopes TA, Bufalino L, Claro PICC, Martins MA, Tonoli GHD, Mendes LM (2018) The effect of surface modifications with corona discharge in pinus and eucalyptus nanofibril films. Cellulose. 25:5017-5033. https://doi.org/10.1007/s10570-018-1948-3

Lu K, Hao N, Meng X, Luo Z, Tuskan GA, Arthur J, Ragauskas AJ (2019) Investigating the correlation of biomass recalcitrance with pyrolysis oil using poplar as the feedstock. Bioresour Technol 289:121589. https://doi.org/10.1016/j.biortech.2019.121589

Malucelli LC, Matos M, Jordão C, Lomonaco D, Lacerda LG, Carvalho Filho M A S, Magalhães WLE (2019) Influence of cellulose chemical pretreatment on energy consumption and viscosity of produced cellulose nanofibers (CNF) and mechanical properties of nanopaper. Cellulose 26:1667-1681. https://doi.org/10.1007/s10570-018-2161-0

Meng X, Pu Y, Yoo CG, Li M, Bali G, Park DY, Gjersing E, Davis MF, Muchero W, Tuskan GA, Tschaplinski TJ, Ragauskas AJ (2017) An in-depth understanding of biomass recalcitrance using natural poplar variants as the feedstock. Chem Sus Chem 10:139-150. https://doi.org/10.1002/cssc.201601303

Miri NE, Abdelouahdi K, Barakat A, Zahouily M, Fihri A, Solhy A, Achaby ME (2015) Bionanocomposite films reinforced with cellulose nanocrystals: rheology of film-forming solutions, transparency, water vapor barrier and tensile properties of films, Carbohyd Polym http://dx.doi.org/10.1016/j.carbpol.2015.04.051

Mirmehdi S, de Oliveira MLC, Hein PRG, Dias MV, Sarantópoulos CIGL, Tonoli GHD, (2018b) Spraying cellulose nanofibrils for improvement of tensile and barrier properties of writing \& printing (W\&P) paper. J Wood Chem Technol 38:1-13. https://doi.org/10.1080/02773813.2018.1432656

Mirmehdi S, Hein PRG, Sarantópoulos CIGL, Dias MV, Tonoli GHD (2018a) Cellulose nanofibrils/nanoclay hybrid composite as a paper coating: Effects of spray time, nanoclay content and corona discharge on barrier and mechanical properties of the coated papers. Food Pack Shelf Life 15:87-94. https://doi.org/10.1016/j.fpsl.2017.11.007

Moon RJ, Martini A, Nairn J, Simonsen J, Youngblood J (2011) Cellulose nanomaterials review: structure, properties and nanocomposites. Chem Soc Rev 40:3941-3994. https://doi.org/10.1039/C0CS00108B

Nechyporchuk O, Belgacem MN, Bras J (2016) Production of cellulose nanofibrils: a review of recent advances. Ind Crops Prod 93:2-25. https://doi.org/10.1016/j. indcrop.2016.02.016.

Nogi M, Handa K, Nakagaito AN, Yano H (2005) Optically transparent bionanofiber composites with low sensivity to refactive index of the polymer matrix. Applied Physic Letters 87:243110. https://doi.org/10.1063/1.2146056

Nogi M, Iwamoto S, Nakagaito AN, Yano H (2009) Optically transparent nanofiber paper. Adv Mater 21:1595-1598. https://doi.org/10.1002/adma.200803174

Nogi M, Kim C, Sugahara T, Inui T, Takahashi T, Suganuma K (2013) High thermal stability of optical transparency in cellulose nanofiber paper. Appl Phys Lett 102:181-911.

https://doi.org/10.1063/1.4804361

Nystrom G, Nyström G, Mihranyan A, Razaq A, Lindström T, Nyholm L, Strømme M (2010) A nanocellulose polyrrole composite based on microfibrillated cellulose from wood. J Phys Chem B 114:4178- 4182. https://doi.org/10.1021/jp911272m 
Ogunsile BO, Oladeji TG (2016) Utilization of banana stalk fiber as reinforcement in low density polyethylene composite. Matéria 21:953-963. http://dx.doi.org/10.1590/s1517-707620160004.0088

Okahisa Y, Furukawa Y, Ishimoto K, Narita C, Intharapichai K, Ohara H (2018) Comparison of cellulose nanofiber properties produced from different parts of the oil palm tree. Carbohyd Polym 198:313-319. https://doi.org/10.1016/j.carbpol.2018.06.089

Padam BS, Tin HS, Chye FY et al. (2014) Banana by-products: an under-utilized renewable food biomass with great potential. J Food Sci Technol 51:3527-3545. https://doi.org/10.1007/s13197-012-0861-2

Pan X, Gilkes N, Saddler JN (2006) Effect of acetyl groups on enzymatic hydrolysis of cellulosic substrates. Holzfor. http://dx.doi.org/10.1515/HF.2006.062

Pei H, Liu L, Zhang X, Sun J (2012) Flow-through pretreatment with strongly acidic electrolyzed water for hemicellulose removal and enzymatic hydrolysis of corn stover. Bioresour Technol 110:292-296. doi:10.1016/j.biortech.2011.12.062

Potulski DC, Viana LC, Muniz GIB, de Andrade AS, Klock U (2016) Characterization of fibrillated cellulose nanofilms obtained at different consistencies. Sci Forest 44:361-372. dx.doi.org/10.18671/scifor.v44n110.09

Qing Y, Sabo R, Wu, Y, Zhu JY, Cai Z (2015) Self-assembled optically transparent cellulose nanofibril films: effect of nanofibril morphology and drying procedure. Cellulose 22:10911102. https://doi.org/10.1007/s10570-015-0563-9

Romero-Bastida CA, Bello-Pérez LA, Velazquez G, Alvarez-Ramirez J (2015) Effect of the addition order and amylose content on mechanical, barrier and structural properties of films made with starch and montmorillonite. Carbohyd Polym 127:195-201. https://doi.org/10.1016/j.carbpol.2015.03.074

Rosa MF, Rosa MF, Medeiros ES, Malmonge JA, Gregorski KS, Wood DF, Mattoso LHC, Glenn G, Orts WJ, Imam SH (2010) Cellulose nanowhiskers from coconut husk fibers: Effect of preparation conditions on their thermal and morphological behavior. Carbohyd Polym 81:8392. https://doi.org/10.1016/j.carbpol.2010.01.059

Samei N, Mortazavi SM, Rashidi AS, Sheikhzadah-Najar S (2008) Na Investigation on the effect of hot mercerization on cotton fabrics made up of open-end yarns. J Appl Sci 8:42044209. 10.3923/jas.2008.4204.4209

Santana JS, do Rosário JM, Pola CC, Otoni CG, Soares NFF, Camilloto GP, Cruz RS (2017) Cassava starch-based nanocomposites reinforced with cellulose nanofibrils extracted from sisal. J Appl Polym Sci 134:44637. https://doi.org/10.1002/app.44637

Scatolino MV, Bufalino L, Mendes LM, Guimarães Júnior M, Tonoli GHD (2017) Impact of nanofibrillation degree of eucalyptus and Amazonian hardwood sawdust on physical properties of cellulose nanofibril films. Wood Sci Technol 51:1095-1115.

https://doi.org/10.1007/s00226-017-0927-4

Scatolino MV, Fonseca CS, da Silva Gomes M et al. (2018) How the surface wettability and modulus of elasticity of the Amazonian paricá nanofibrils films are affected by the chemical changes of the natural fibers. Eur J Wood Prod 76:1581-1594. https://doi.org/10.1007/s00107018-1343-7 
Siró I, Plackett D (2010) Microfibrillated celulose and new composite materials: a review. Cellulose 17:459-464. DOI:10.1007/s10570-010-9405-y

Silva EL, Reis CA, Vieira HC, Santos JX, Nisgoski S, Saul CK, Muñiz GIB (2020) Evaluation of poly (vinyl alcohol) addition effect on nanofibrillated cellulose films characteristics. Cerne 26:1-8. doi:10.1590/01047760202026012654

Silverstein RM, Webster FX (2000) Spectrometric identification of organic compounds. $6^{\mathrm{a}}$ ED. LTC editor 77-88, 2000.

Serra A, González I, Oliver-Ortega H, Tarrès Q, Delgado-Aguilar M, Mutjé P (2017) Reducing the amount of catalyst in TEMPO-Oxidized cellulose nanofibers: effect on properties and cost. Polymers 9:557. https://doi.org/10.3390/polym9110557

\section{Sixta H (2006) Handbook of Pulp. 1. ed., Weinheim: Wiley-VCH Verlag. 1316p 2006.}

Sollins P, Homann P, Caldwell BA (1996) Stabilization and destabilization of soil organic matter: mechanisms and controls. Geoderma 74:65-105. https://doi.org/10.1016/S00167061(96)00036-5

Souza LO, Lessa OA, Dias MC, Tonoli GHD, Rezende DVB, Martins MA, Neves ICO, de Resende JV, Carvalho EEN, Vilas Boas EVB, de Oliveira JR, Franco M (2019) Study of morphological properties and rheological parameters of cellulose nanofibrils of cocoa shell (Theobroma cacao L.). Carbohyd Polym 214:152-158.

https://doi.org/10.1016/j.carbpol.2019.03.037

Souza O, Federizzi M, Coelho B, Wagner TM, Wisbeck E (2010) Biodegradation of lignocellulosics residues generated in banana cultivation and its valorization for the production of biogas. Rev Bras Eng Agr Amb 14:438-443. https://doi.org/10.1590/S141543662010000400014

Spence KL, Venditti RA, Habibi Y, Rojas OJ, Pawlak JJ (2010) The effect of chemical composition on microfibrillar cellulose films from wood pulps: Mechanical processing and $\begin{array}{llll}\text { physical properties. } & \text { Bioresour } & \text { Technol } & \text { 101:5961-5968. }\end{array}$ https://doi.org/10.1016/j.biortech.2010.02.104

Stark NM (2016) Opportunities for cellulose nanomaterials in packaging films: a review and future trends, J Renew Mater 4:313-326. doi:10.7569/JRM.2016.634115

Stelte W, Sanadi AR (2009) Preparation and characterization of cellulose nanofibrils from two commercial hardwood and softwood pulps. Ind Eng Chem Res 48:11211-11219.

https://doi.org/10.1021/ie9011672

TAPPI - Technical association of the pulp and paper industry. T 220-om01 (2004) Physical testing of pulp handsheets. In: Tappi Test Methods. TAPPI Press, Norcross.

TAPPI - Technical association of the pulp and paper industry. T 410-om02 (2004) Grammage of paper and paperboard. In: Tappi Test Methods. TAPPI Press, Norcross.

TAPPI - Technical association of the pulp and paper industry. T 412-om02 (2004) Moisture in pulp, paper and paperboard. in: Tappi test methods. TAPPI Press, Norcross. 
Thomas MG, Abraham E, Jyotishkumar P, Maria HJ, Pothen LA, Thomas S (2015)

Nanocelluloses from jute fibers and their nanocomposites with natural rubber: preparation and characterization. Int J Biol Macromol 81:768-777.

https://doi.org/10.1016/j.ijbiomac.2015.08.053

Toivonen MS, Kaskela A, Rojas OJ, Kauppinen EI, Ikkala O (2015) Ambient-dried cellulose nanofibril aerogel membranes with high tensile strength and their use for aerosol collection and templates for transparent, flexible devices. Adv Func Mater 25:6618-6626.

https://doi.org/10.1002/adfm.201502566

Tonoli GHD, Holtman KM, Glenn G, Fonseca AS, Wood D, Williams T, de Sa VA, Torres L, Klamczynski A, Orts WJ (2016) Properties of cellulose micro/nanofibrils obtained from eucalyptus pulp fiber treated with anaerobic digestate and high shear mixing. Cellulose 23:1239-1256. https://doi.org/10.1007/s10570-016-0890-5

Trevisan R, Rosa M, Haselein CR, Santini EJ, Gatto DA (2017) Fiber dimensions and their relationship with the transition age between juvenile and mature wood of Eucalyptus grandis w. Hill ex Maiden. Ciência Florestal 27:1385-1393. https://doi.org/10.5902/1980509830220

Vardhini KJV, Murugan R, Selvi Tamil SC, Surjit R (2016) Optimisation of alkali treatment of banana fibres on lignin removal. Indian J Fibre Textile Res 41:156-160.

http://op.niscair.res.in/index.php/IJFTR/article/view/7295/847

Velásquez-Cock J, Castro $\mathrm{C}$, Gañán $\mathrm{P}$, Osorio $\mathrm{M}$, Putaux J-L, Serpa A, Zuluaga $\mathrm{R}$ (2016) Influence of the maturation time on the physico-chemical properties of nanocellulose and associated constituents isolated from pseudostems of banana plant c.v. Valery. Ind Crop Prod 83:551-560. doi:10.1016/j.indcrop.2015.12.070

Weiss ND, Thygesen LG, Felby C, Roslander C, Gourlay K (2017) Biomass-water interactions correlate to recalcitrance and are intensified by pretreatment: An investigation of water constraint and retention in pretreated spruce using low field NMR and water retention value techniques. Biotechnol Progress 33:146-153. doi:10.1002/btpr.2398

Widsten P, Tuominen S, Qvintus-Leino P, Laine JE (2004) The influence of high defibration temperature on the properties of medium-density fiberboard (MDF) made from laccase treated softwood fibers. Wood Sci Technol 38:521-528. https://doi.org/10.1007/s00226-003-0206-4

Yue Y, Han J, Han G, Zhang Q, French AD, Wu Q (2015) Characterization of cellulose I/II hybrid fibers isolated from energycane bagasse during the delignification process: morphology, crystallinity and percentage estimation. Carbohydr. Polym. 133, 438-447.

https://doi.org/10.1016/j.carbpol.2015.07.058

Zhang C, Nair SS, Chen H, Yan N, Farnood R, Li F (2019) Thermally stable, enhanced water barrier, high strength starch bio-composite reinforced with lignin containing cellulose nanofibrils. Carbohydr Polym 115626. doi:10.1016/j.carbpol.2019.115626

Zhang L, Xue F, Du W, Han C, Zhang C, Wang Z (2014) Transparent paper-based triboelectric nanogenerator as a page mark and anti-theft sensor. Nano Res 7:1215-1223.

DOI 10.1007/s12274-014-0484-1

Zhou S, Liu P, Wang M, Zhao H, Yang J, Xu F (2016) Ustainable, reusable, and superhydrophobic aerogels from microfibrillated cellulose for highly effective oil/water separation. ACS Sust Chem Eng 4:6409-6416. https://doi.org/10.1021/acssuschemeng.6b01075 
Zhu H, Xiao Z, Liu D, Li Y, Weadock NJ, Fang Z, Huang J, Hu L (2013) Biodegradable transparent substrates for flexible organic-light-emitting diodes. Energ Environ Sci 6:21052111. https://doi.org/10.1039/C3EE40492G

Zhu JY, Sabo R, Luo X (2011) Integrated production of nano-fibrillated cellulose and cellulosic biofuel (ethanol) by enzymatic fractionation of wood fibers. Green Chem 13:1339-1344. https://doi.org/10.1039/C1GC15103G

Zimmermann T, Bordeanu N, Strub E (2010) Properties of nanofibrillated cellulose from different raw materials and its reinforcement potential. Carbohyd Polym 79:1086-1093.

https://doi.org/10.1016/j.carbpol.2009.10.045

Zuber M, Zia KM, Bhatti IA, Ali Z, Arshad MU, Saif MJ (2012) Modification of cellulosic fibers by UV-irradiation. Part II: After treatments effects. Int J Biol Macromol 51:743-748. https://doi.org/10.1016/j.ijbiomac.2012.07.001

Zuluaga R, Putaux J-L, Cruz J, Vélez J, Mondragón I, Gaňan P, Cruz J, Vélez J, Mondragón I, Gaňan P (2009) Cellulose microfibrils from banana rachis:effect of alkaline treatments on structural and morphological features. Carbohydr Polym 76:51-59, http://dx.doi.org/10.1016/j.carbpol.2008.09.024 
Figures

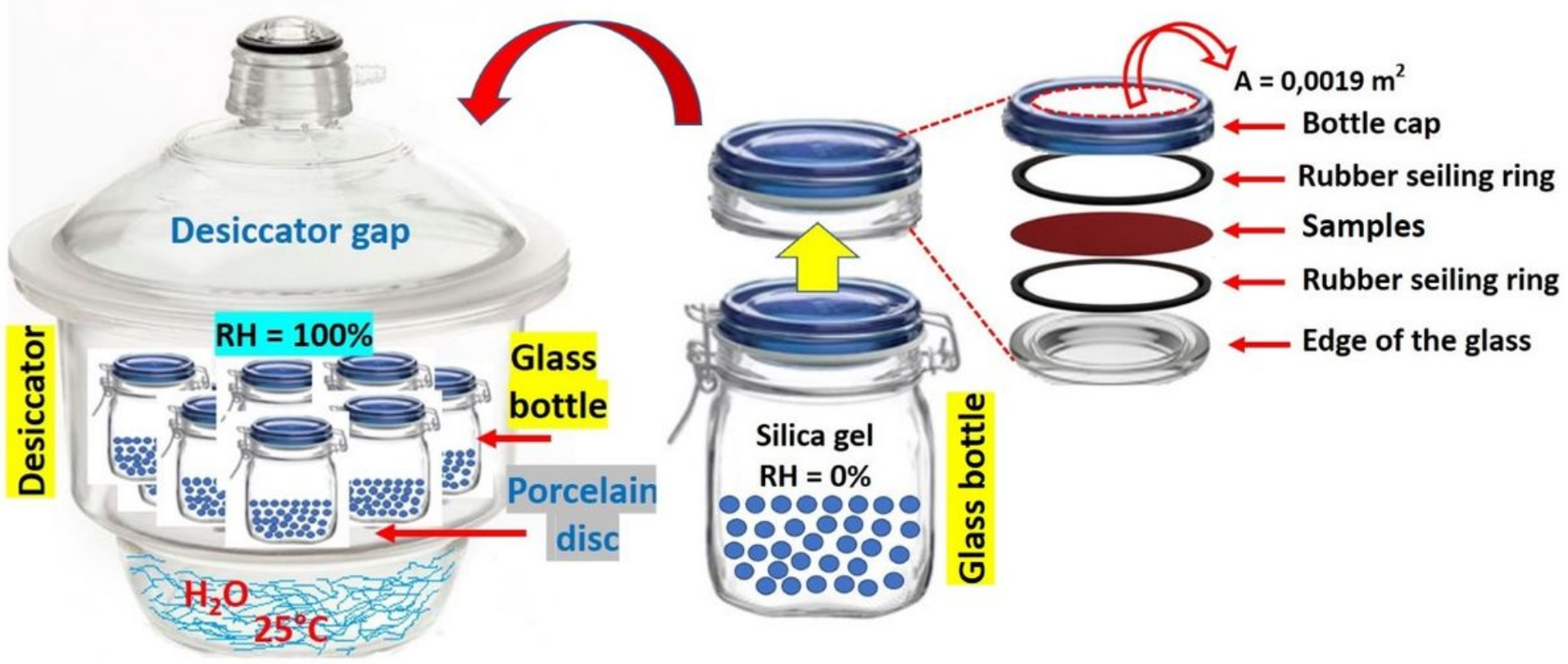

Figure 1

Scheme of permeability cell methodology for evaluation of the permeability of the films/nanopapers. 


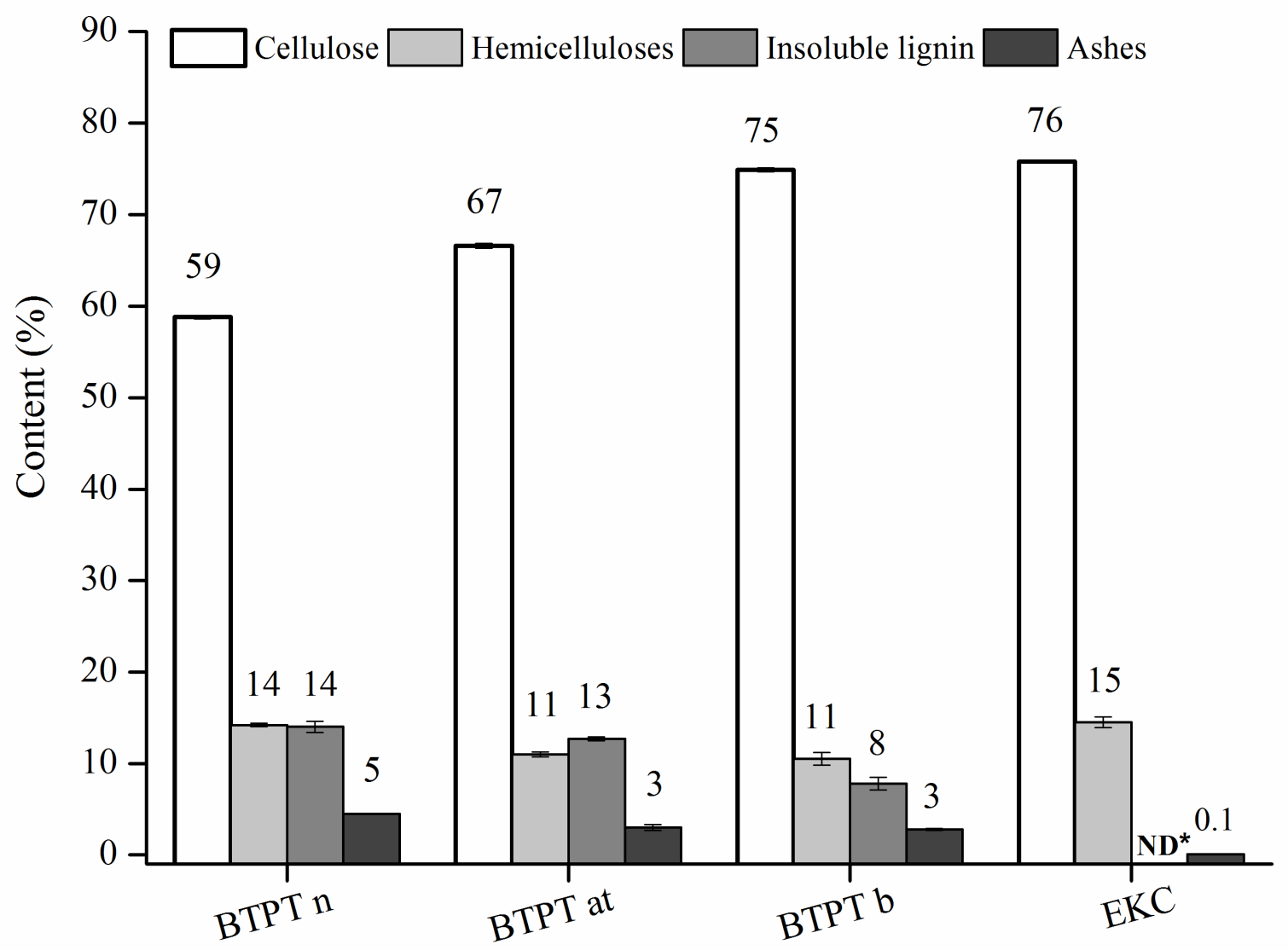

Figure 2

Chemical composition of the BTPT and EKC; ${ }^{*} \mathrm{ND}=$ not detected; $\mathrm{n}=$ natural; at = alkaline treated; $\mathrm{b}=$ bleached. 

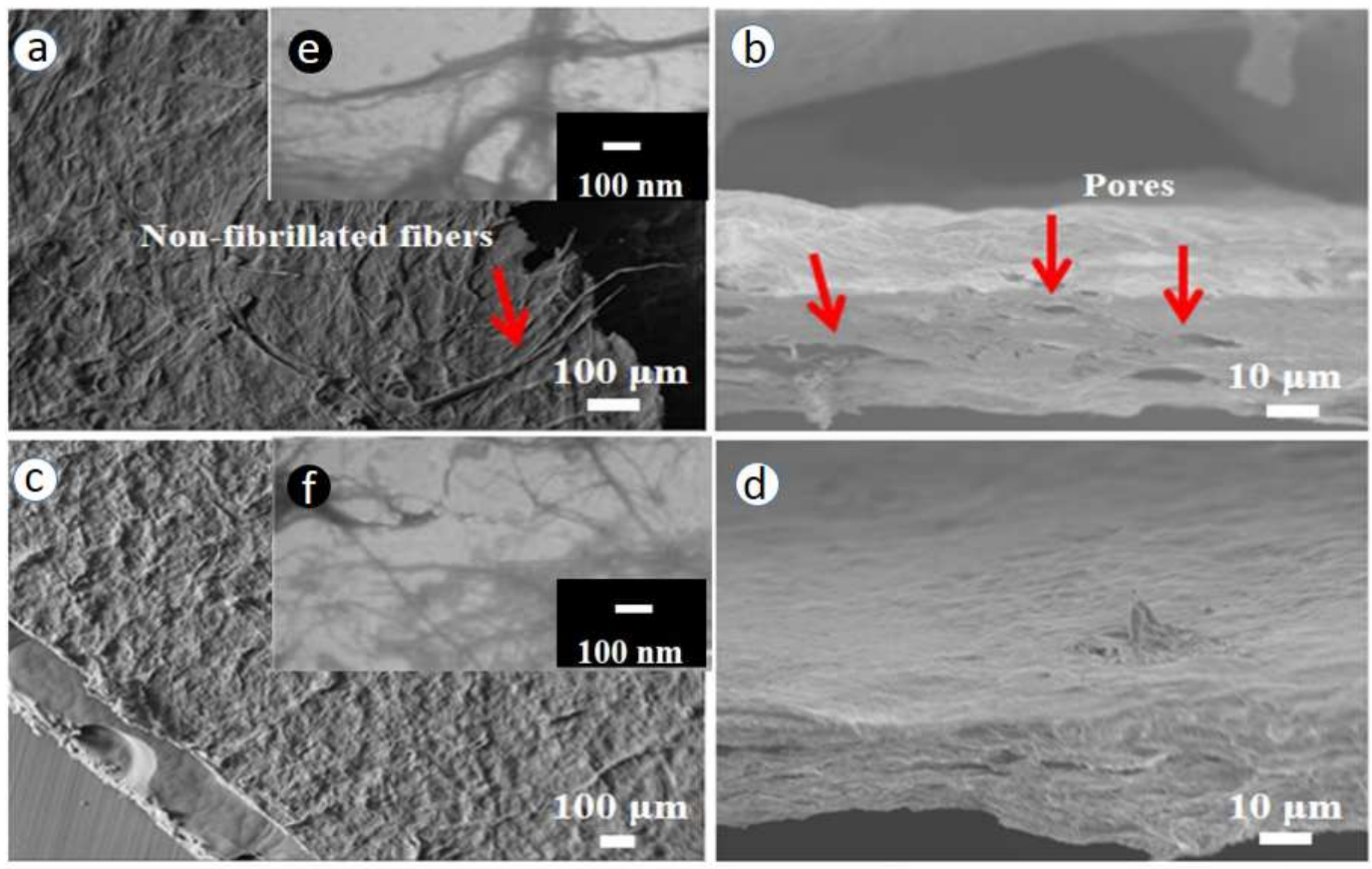

\section{Figure 3}

Typical scanning electron microscopy (SEM) images of BTPT films/nanopapers: $a$ ) and b) surface and fracture view, respectively (20 passages); c) and d) surface and fracture view, respectively (40 passages); e) and f) SEM/FEG micrographs of the CNFs suspension, respectively, after 20 and 40 passages. 

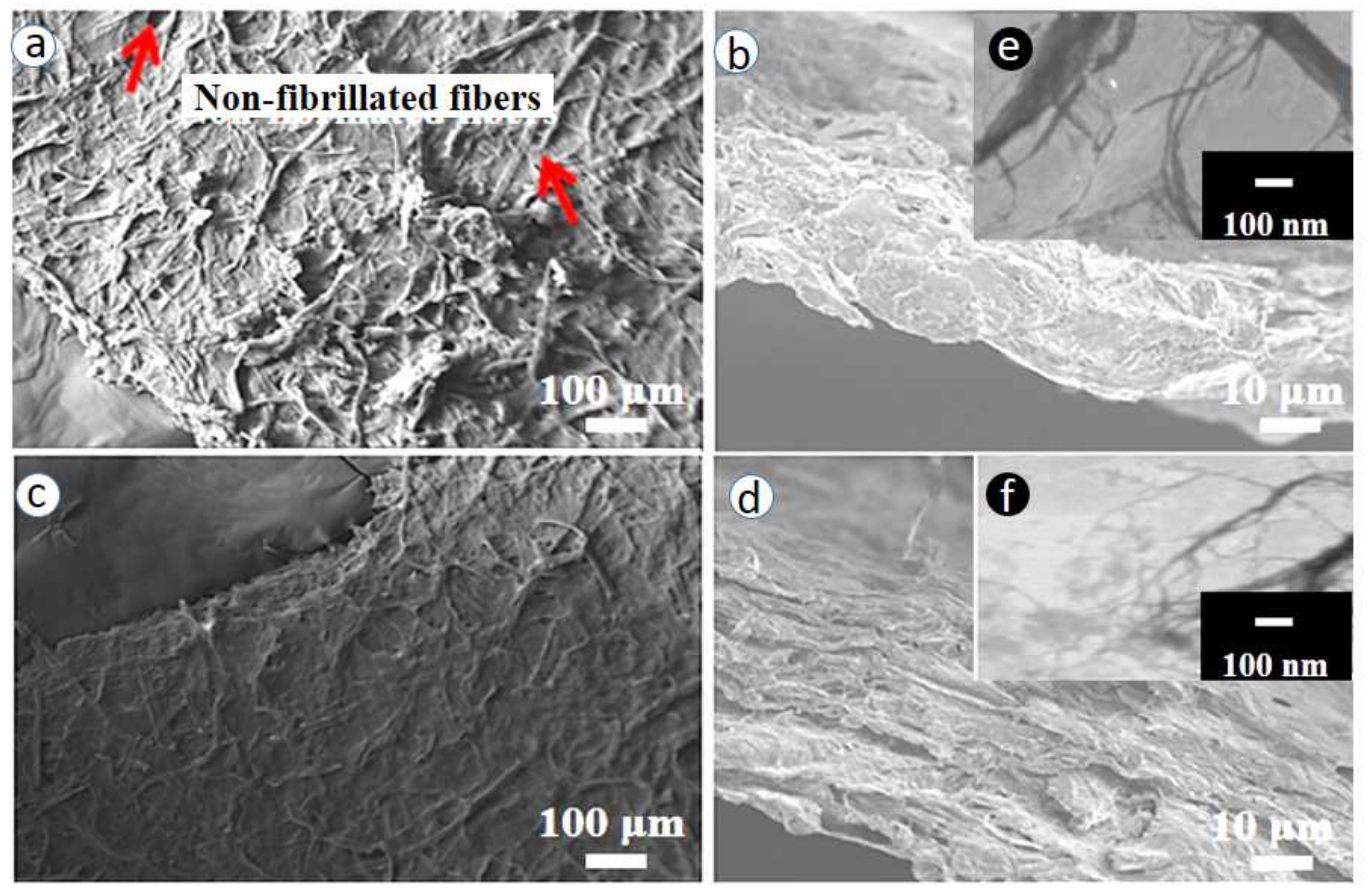

\section{Figure 4}

Typical scanning electron microscopy (SEM) micrographs of EKC films/nanopapers: $a$ ) and b) surface and fracture view, respectively (20 passages); c) and d) surface and fracture view, respectively (40 passages); e) and f) SEM/FEG micrographs of the CNFs suspension, respectively, after 20 and 40 passages. 


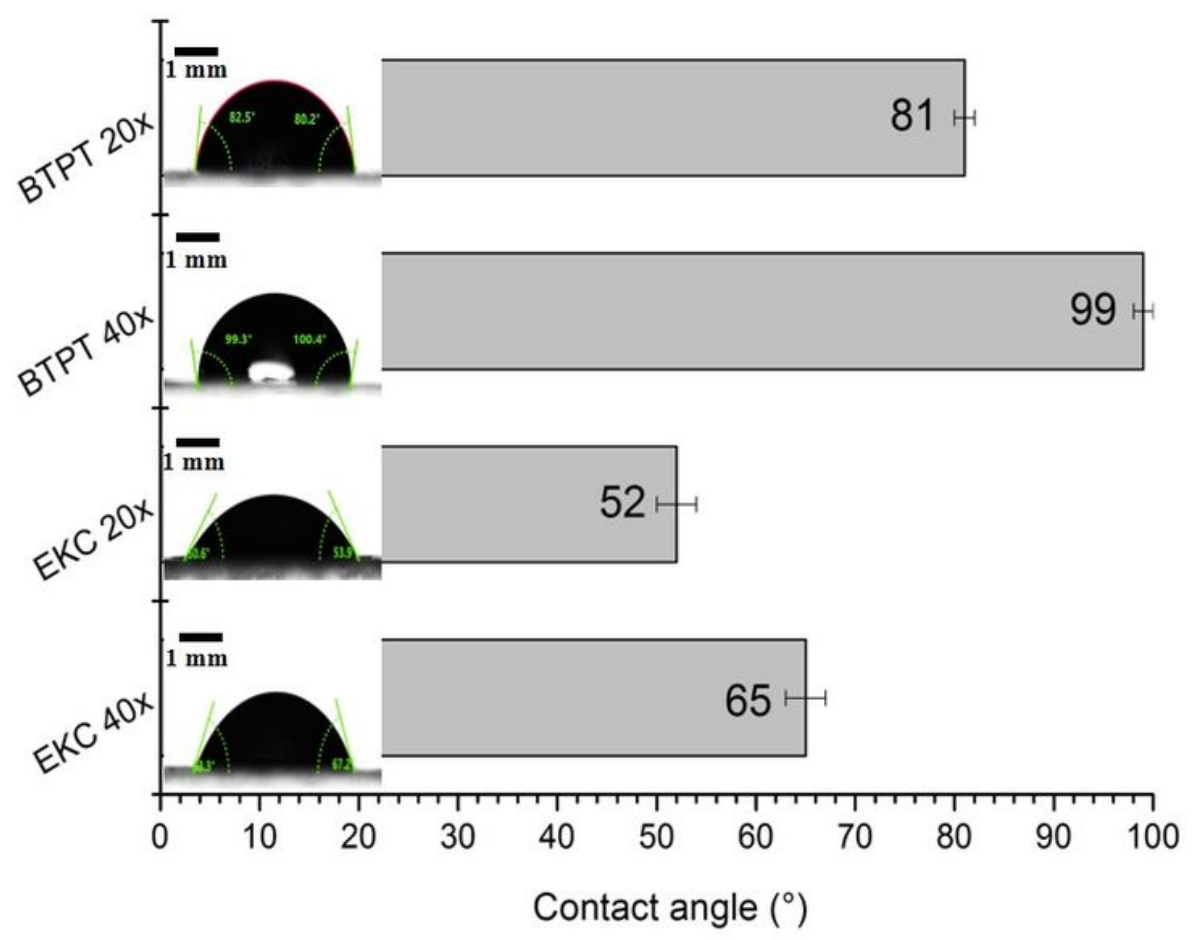

Figure 5

Average contact angle (after $2 \mathrm{~s}$ ) of water with the BTPT and EKC films/nanopapers obtained after 20 and 40 passages through the grinder fibrillator. 


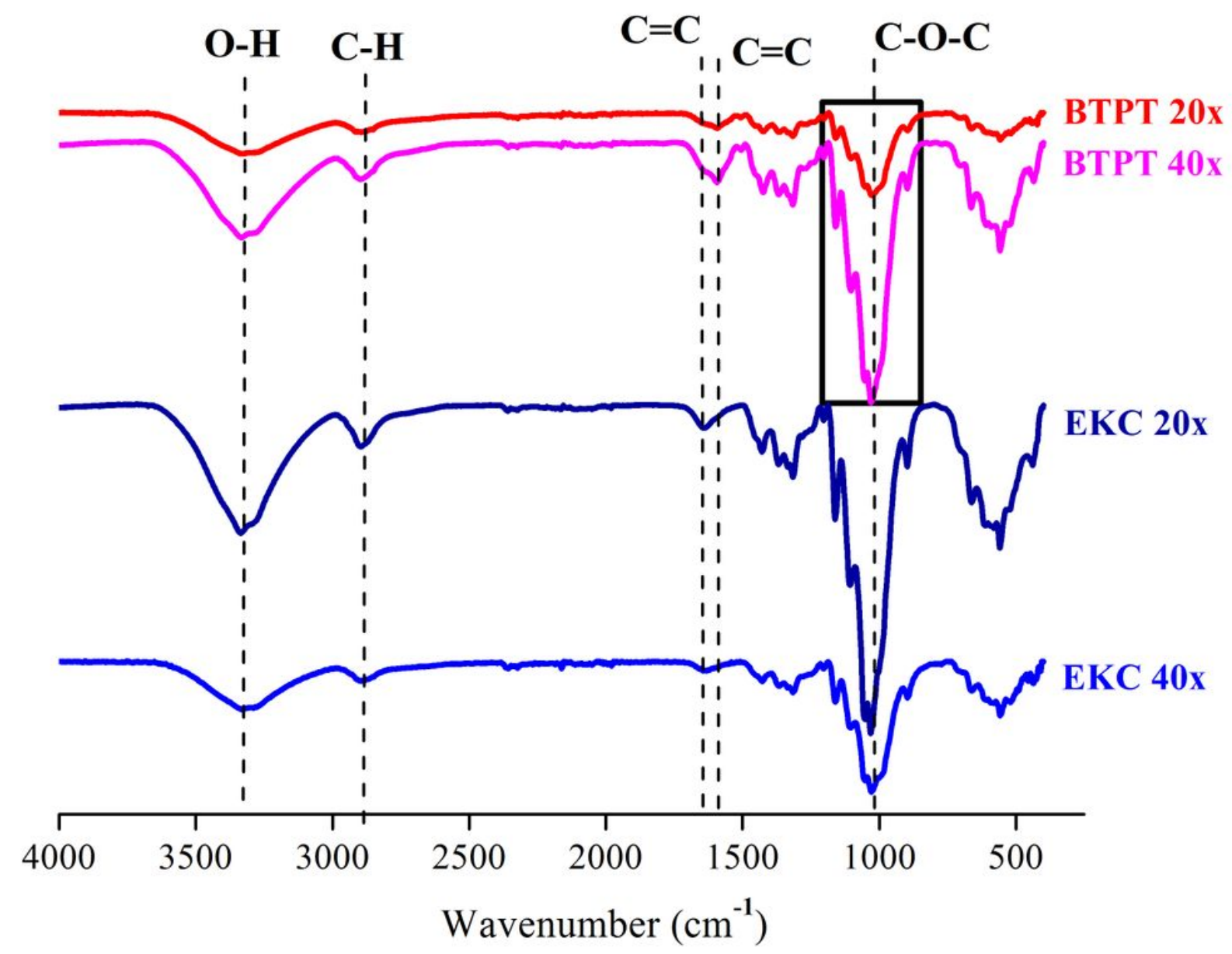

Figure 6

Typical FTIR spectra for BTPT and EKC films/nanopapers obtained after 20 and 40 passages through the fibrillator. 


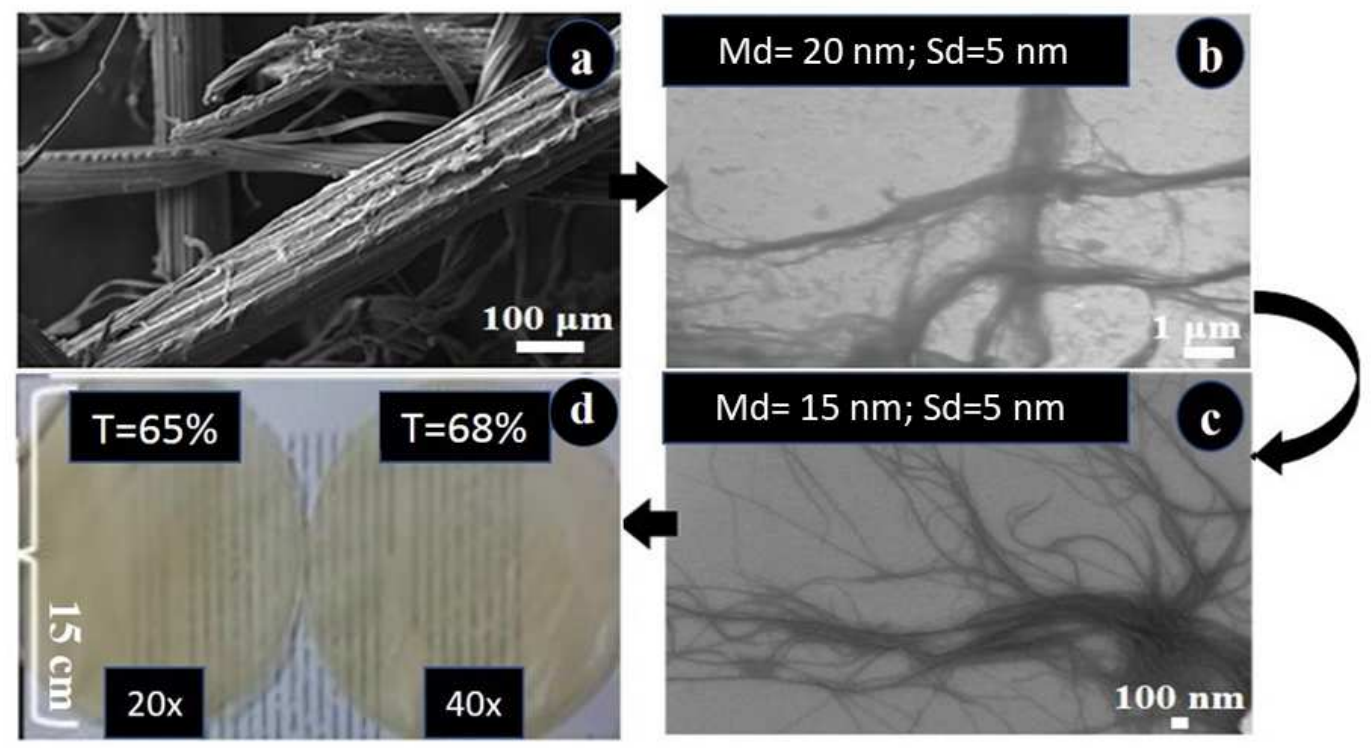

\section{Figure 7}

Typical images of the banana tree pseudostem (BTPT) structure and films/nanopapers: (a) SEM micrographs of the fibers, (b) SEM/FEG micrographs of the CNFs 20x, and (c) CNFs 40x; (d) visual aspect and light transmittance $(\mathrm{T})$ of the films/nanopapers; $\mathrm{Md}=$ average diameter; $\mathrm{Sd}=$ standard deviation. 


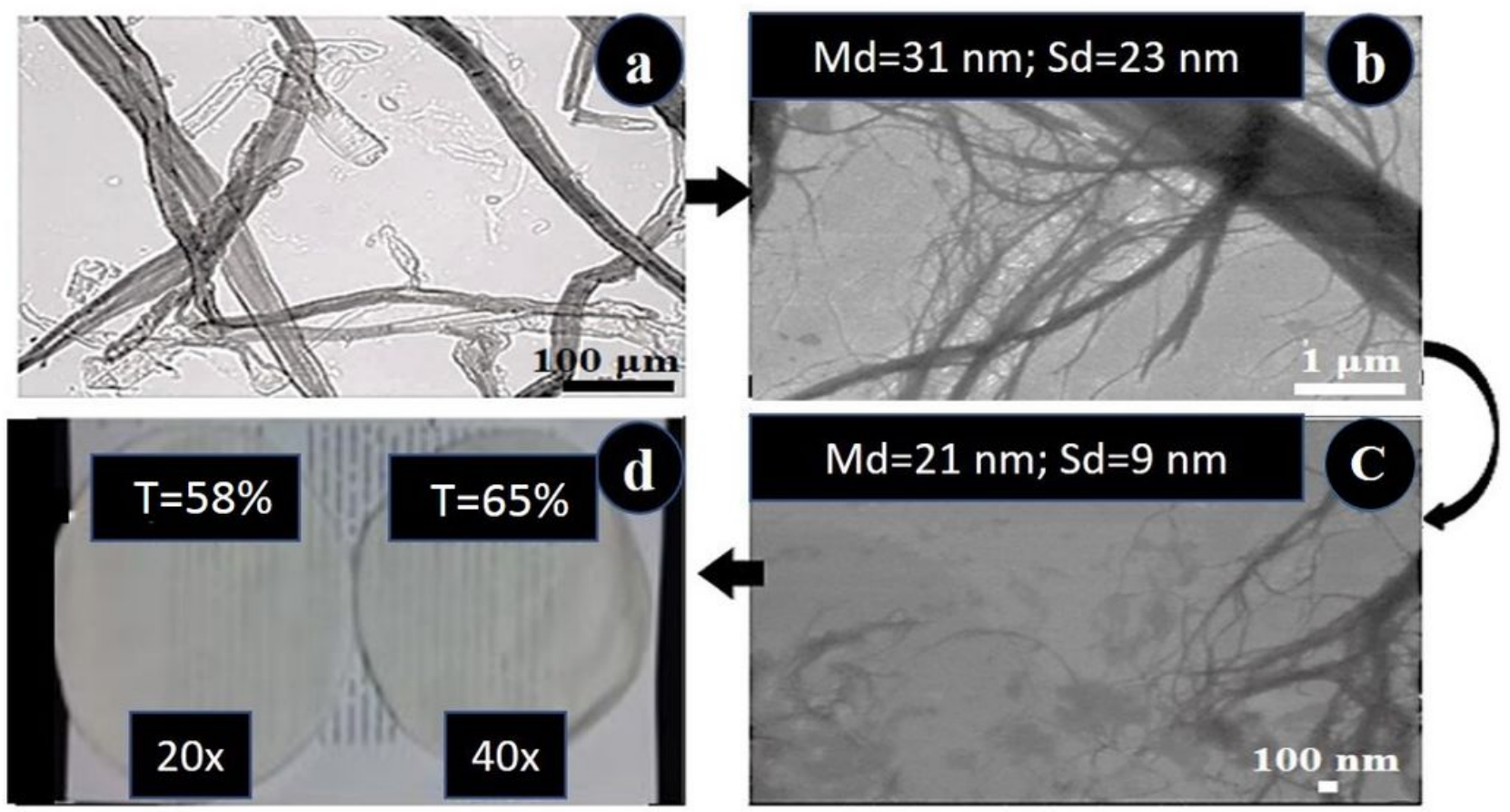

\section{Figure 8}

Typical images of the Eucalyptus kraft cellulose (EKC) structure and films/nanopapers: (a) light microscopy image of the fibers, (b) SEM/FEG micrographs of the CNFs 20x, and (c) CNFs 40x; (d) visual aspect and light transmittance $(\mathrm{T})$ of EKC films/nanopapers; $\mathrm{Md}=$ average diameter; $\mathrm{Sd}=$ standard deviation. 

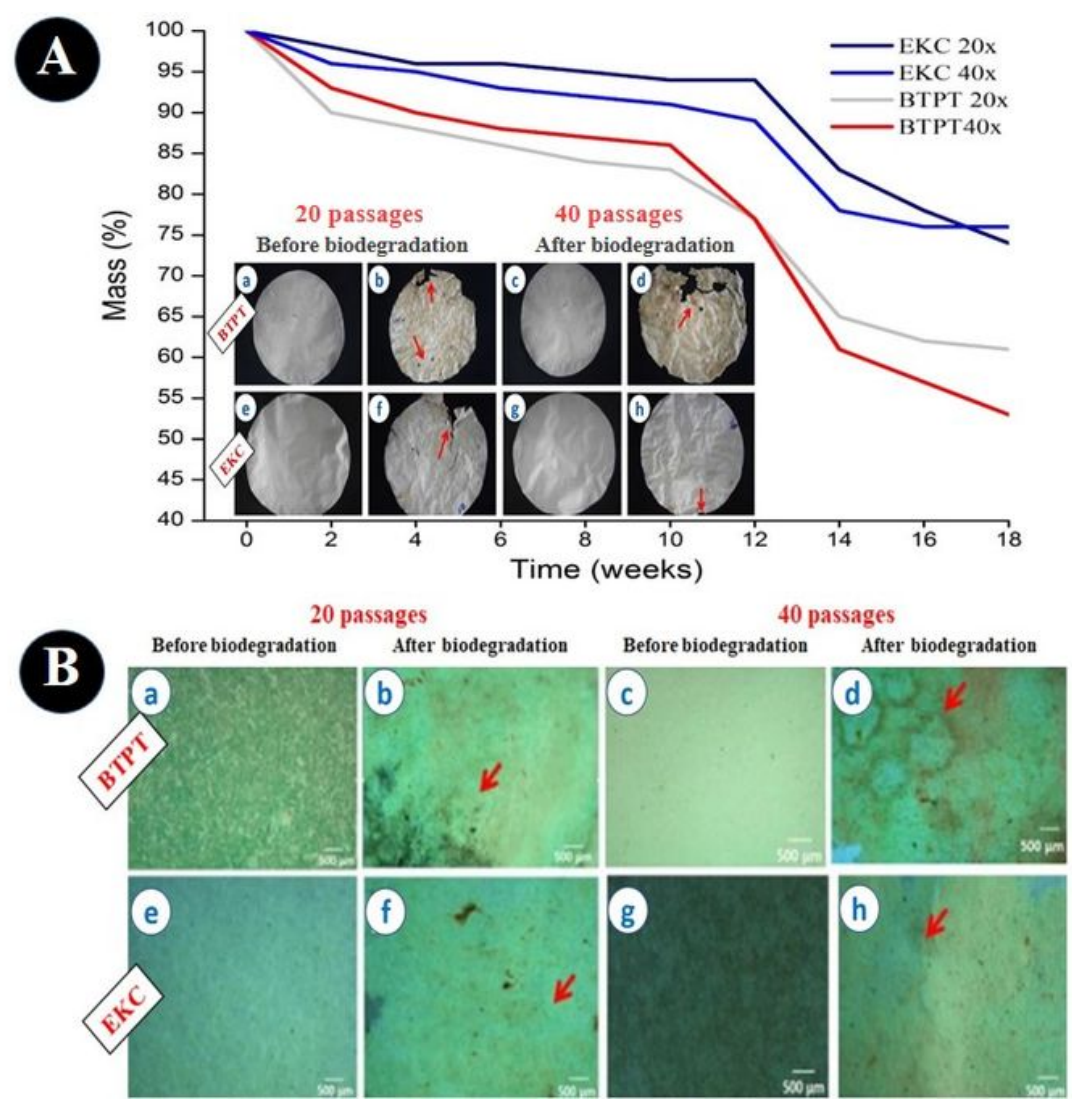

\section{Figure 9}

A) Mass loss of the films/nanopapers along the biodegradation and visual aspect of the samples before and after 18 weeks in simulated soil: from (a) to (d) BTPT films/nanopapers (20 and 40 passages) before and after biodegradation; from (e) to (h) EKC films/nanopapers (20 and 40 passages) before and after biodegradation; B) Typical optical microscopy images of the samples after 18 weeks after soil incubation. Red arrows show pores and stains. From (a) to (d) BTPT nanostructured films/nanopapers (20 and 40 passages) before and after biodegradation; from (e) to (h) EKC nanostructured films/nanopapers (20 and 40 passages) before and after biodegradation.

\section{Supplementary Files}

This is a list of supplementary files associated with this preprint. Click to download.

- Newgraphicalabstract.jpg 